University of Nebraska - Lincoln

DigitalCommons@University of Nebraska - Lincoln

Improvement of Perennial Forage Species as Feedstock for Bioenergy

William Anderson

USDA-ARS

Michael Casler

USDA-ARS, michael.casler@ars.usda.gov

Brian S. Baldwin

Mississippi State University, bsb2@msstate.edu

Follow this and additional works at: https://digitalcommons.unl.edu/usdaarsfacpub

Part of the Agricultural Science Commons

Anderson, William; Casler, Michael; and Baldwin, Brian S., "Improvement of Perennial Forage Species as Feedstock for Bioenergy" (2008). Publications from USDA-ARS / UNL Faculty. 248.

https://digitalcommons.unl.edu/usdaarsfacpub/248

This Article is brought to you for free and open access by the U.S. Department of Agriculture: Agricultural Research Service, Lincoln, Nebraska at DigitalCommons@University of Nebraska - Lincoln. It has been accepted for inclusion in Publications from USDA-ARS / UNL Faculty by an authorized administrator of DigitalCommons@University of Nebraska - Lincoln. 


\title{
Improvement of Perennial Forage Species as Feedstock for Bioenergy
}

\author{
William F. Anderson, ${ }^{1}$ Michael D. Casler ${ }^{2}$ and Brian S. Baldwin ${ }^{3}$ \\ 1 USDA-ARS, Crop Genetics and Breeding Research Unit, Tifton, GA, \\ bill.anderson@ars.usda.gov \\ 2 USDA-ARS, U.S. Dairy Forage Research Center, Madison, WI, \\ michael.casler@ars.usda.gov \\ 3 Plant and Soil Sciences, Mississippi State University, Starkville, MS, \\ bbaldwin@pss.msstate.edu
}

\subsection{Introduction}

Both native and non-native forage species other than switchgrass are less commonly considered as potential lignocellulosic feedstocks for bioenergy in the United States. These species hold potential as bioenergy feedstocks because of the experience and infrastructure that is already in place for management and harvest, and in certain areas of the country they have greater yield potential than switchgrass or other feedstocks. The forage grasses consist of temperate cool-season (most commonly $\mathrm{C}_{3}$ ) grasses as well as tropical or sub-tropical warm-season $\left(\mathrm{C}_{4}\right)$ grasses. Some legume species may also play a significant role in supplying useful bioenergy feedstocks. Most have been researched and used as a pasture or hay crop and are currently grown over millions of hectares of fertile as well as Conservation Reserve Program (CRP) land throughout the United States. Research on genetic variability and breeding systems has revealed great potential in improving these crops for bioenergy. However, research on the majority of these species has only recently begun concerning the potential as a renewable energy resource. The largest hurdles for forage crops to become a significant portion of the biomass needed for renewable energy are the current high price for these hays (as feed for livestock) and the high water and fertilizer inputs needed for production. This chapter will not attempt to address all of the 10,000 species of grasses, of which $47 \%$ are $C_{4}$ (Sage et al. 1999) or the numerous perennial forage legumes, but will be limited to those considered to have the greatest potential of contributing to the billions of tons of biomass needed for replacement of fossil fuels over the coming years.

A mixture of cool-season grasses and legumes constitute pasture and hay crops of the temperate north and western mountain areas of the United States (United States Department of Agriculture (USDA) Plant hardiness zones 3-6). Tall fescue grass (Festuca arundinacea Schreb.), timothy grass (Phleum pratense L.), orchardgrass 
(Dactylis glomerata L.), smooth bromegrass (Bromus inermis Leyss.), and reed canarygrass (Phalaris arundinacea L.) are the predominant pasture grasses and alfalfa (Medicago sativa L.) and the clovers (Trifolium spp.) are the primary legumes of the eastern temperate, Northwest and California coastal regions. Numerous native rangeland species predominate in the inter-mountain regions. Of these species, alfalfa, reed canarygrass and the wildryes (Leymus spp.) are currently being investigated as potential lignocellulosic feedstocks. These species will be discussed in Sections $12.2-12.4$.

Warm-season $\left(\mathrm{C}_{4}\right)$ grasses are particularly adapted to the warmer climates of the United States (Plant hardiness zones 7-9). Yields of these grasses can be upwards of 20-30 Mg ha ${ }^{-1}$ depending upon moisture and soil fertility. A number of native species have been used for livestock grazing, but the majority of the managed pastures in the southern U.S. are non-native bermudagrass (Cynodon spp.) and bahiagrass (Paspalum notatum L.). Napiergrass (Pennisetum purpureum), which is a significant forage for much of the tropical world, has also been introduced and improved for use as a forage for parts of Florida, though little is currently grown for that purpose. Some of these species, as well as big bluestem and eastern gamagrass, are being evaluated for their potential as bioenergy crops and will be discussed in Sections $12.5-12.8$.

\subsection{Reed Canarygrass}

\subsubsection{Botanical Description}

Two Phalaris species are used extensively for forage production: reed canarygrass (P. arundinacea L.) in cool, humid, temperate climates, and phalaris (P. aquatica L.) in Mediterranean climates. Within this genus, interest in bioenergy feedstock production is focused on reed canarygrass. This species has a circumglobal distribution in the northern hemisphere, occupying many habitats within North America, Europe, and Asia (Anderson 1961). It is best adapted to low-lying areas subject to short-term flooding. In North America, it is highly vilified as an opportunist that has taken advantage of sedimentation and nutrient loading in wetlands to colonize and form vast monocultures within these ecosystems (Green and Galatowitsch 2001; Maurer and Zedler 2002).

Reed canarygrass is a long-lived perennial that can reproduce sexually by seed that is readily dispersed by a highly efficient shattering mechanism, and asexually by rhizomes or axillary buds on lower stem nodes. Both seed and rhizomes can live for long periods of time, with effective dormancy mechanisms that contribute to the longevity of the species. Reed canarygrass has two cytotypes, the widely-distributed tetraploid $(2 n=4 x=28)$ and a hexaploid $(2 n=6 x=42)$, which originated on the Iberian Peninsula (McWilliam and Neal-Smith 1962). Nearly all reed canarygrass cultivars are derived from the tetraploid form. Reed canarygrass is highly selfincompatible and wind-pollinated, with extremely low rates of self-pollination, making it relatively easy to manipulate by hybridization. 


\subsubsection{Management and Bioprocessing}

Reed canarygrass can be planted in spring or late summer, typically in clean and firm seedbeds. Seedlings grow very slowly and establishment is a long, slow process that requires diligent and patient management during the establishment year (Buxton and Wedin 1970). Due to slow establishment rates, maximum production of reed canarygrass stands is not achieved until the second or third year of production and spring seedings are more effective than late summer seedings at reducing the yield production lag due to establishment. Annual weeds are the biggest impediment to successful establishment, requiring frequent clipping to maintain an open canopy and minimize the effects of competition (Sheaffer et al. 1990).

Interest in reed canarygrass as a bioenergy crop derives from its status as a highly persistent and long-lived temperate grass with relatively high biomass yield potential (Wright 1990; Buxton and Anderson 1992). Its superior drought and water-logging tolerance confer adaptation to a wide range of soil types, habitats, and management systems. It has a deep and profuse root system that contributes to its wide range of stress tolerances (Bennett and Doss 1960). Reed canarygrass is also widely adapted to a range of harvest managements and nitrogen $(\mathrm{N})$ fertility levels (Decker et al. 1967; Marten et al. 1979; Marten and Hovin 1980). It responds well to N applications, either as inorganic fertilizer, manure, or sewage effluent. Maximum biomass production is achieved under a two-harvest management system (Marten et al. 1979; Marten and Hovin 1980). Biomass yields generally range from about $10-15 \mathrm{Mg} \mathrm{ha}^{-1}$ on a dry-matter basis.

\subsubsection{Genetics and Breeding}

Traditional breeding techniques have been used to take advantage of its high selfincompatibility and natural cross pollination. Crosses can be easily made by mutual pollination without emasculation in the glasshouse or the field. Glasshouse crossing is accomplished with potted plants that have been placed in glass-covered cold frames during late autumn and early winter for floral induction, before transfer to the glasshouse and gradual increase in both temperature and daylength (Casler and Hovin 1985). Field crossing is accomplished with large (1-m diameter $\times 2$-m height) crossing bags supported by frames made from PVC pipes, allowing sufficient seed for yield trials of hybrids. Commercial cultivars are synthetics, typically originating from 5 to 20 clones, largely because insufficient research has been conducted on hybrid seed production systems, which could be facilitated by asexual propagation of parental clones (Casler and Hovin 1980). The largest known germplasm collection is present at the United States Dairy Forage Research Center at Madison, WI where USDA-Agricultural Research Service (ARS) maintains over 900 accessions. The USDA-National Plant Germplasm System (NPGS) lists 106 plant introductions (USDA-ARS, National Genetic Resources Program 2007).

Because of its outcrossing and polyploid nature, individual populations of reed canarygrass contain large reservoirs of genetic variability. Compared to most temperate grasses, reed canarygrass contains a relatively large amount of variability for morphological traits, such as leaf width, leaf angle, leaf rigidity, stem diameter, and 
number of nodes, some of which can be used as a predictor of biomass production (Casler and Hovin 1985). Considerable ecotypic variation exists within reed canarygrass (Sachs and Coulman 1983), presumably related to habitat differentiation and natural selection.

In North America, there is a long history of introduction from European reed canarygrass populations, beginning in the 1890s and rapidly spreading throughout temperate climatic zones (Sheaffer and Marten 1995; Carlson et al. 1996). The spread of European germplasm throughout temperate North America combined with the morphological similarity of North American and European forms, have obscured any ability to distinguish native from introduced types. A study of amplified fragment length polymorphic (AFLP ${ }^{\circledR}$ ) DNA markers (see Chapter 6) of reed canarygrass cultivars developed by North American and European breeding programs revealed some differences among cultivars, but no overall difference between North American and European cultivars (Fig. 12.1). These results suggest that European germplasm has likely contributed to the development of most North American cultivars, largely as selections made from old pastures that have likely undergone many years of natural selection.

Because of its importance as a pasture grass, most efforts to develop improved populations or cultivars have focused on solving problems related to agronomic performance or livestock utilization. The most intensive and sustained efforts in breeding reed canarygrass, by far, have been to develop new cultivars with reduced and/or modified alkaloid profiles (Marten 1989). Tryptamine and $\beta$-carboline alkaloids are harmful to livestock, causing cancer, hair loss, diarrhea, and other disorders. These compounds are simply inherited by two genes that control their presence or absense from plant tissues (Marum et al. 1979). Gramine (3-(dimethylamino methyl)-indole), which is synthesized only in the double recessive genotype, causes loss of appetite and reduced intake. New cultivars of reed canarygrass have reduced gramine concentrations and no tryptamine or $\beta$-carboline alkaloids. The implications of reduced and/or modified alkaloid profiles on ecological fitness, including potential reductions in resistance to feeding by insects, have not been studied.

\subsubsection{Future Outlook for Reed Canarygrass}

There is considerable potential to improve reed canarygrass as a dedicated bioenergy crop. Seedling vigor and establishment potential can be improved by selection and breeding (Casler and Undersander 2006). There is considerable genetic variation for biomass yield (Sachs and Coulman 1983) and for quality traits that relate to fermentation characteristics of plant biomass (Marum et al. 1979). Breeding reed canarygrass as a dedicated bioenergy crop holds some distinct advantages over breeding for pasture production, most notably the ability to ignore alkaloid profiles or to utilize plants with high concentrations of alkaloids as a potential aid in reducing insect herbivory. The status of reed canarygrass as an 'invader' or 'invasive species' will be a significant impediment to deployment of dedicated bioenergy cultivars of this species, requiring management programs to eliminate or minimize spread of seed into local wetlands and to educate the public on the value of using a diverse array of bioenergy crops to meet the growing demands for biomass in the energy industry. 
Human resources are the largest limitation to future progress, with only one reed canarygrass breeding program still active in North America (USDA-ARS, Madison, WI), reduced from its zenith of six different breeding programs in the late 1970's.

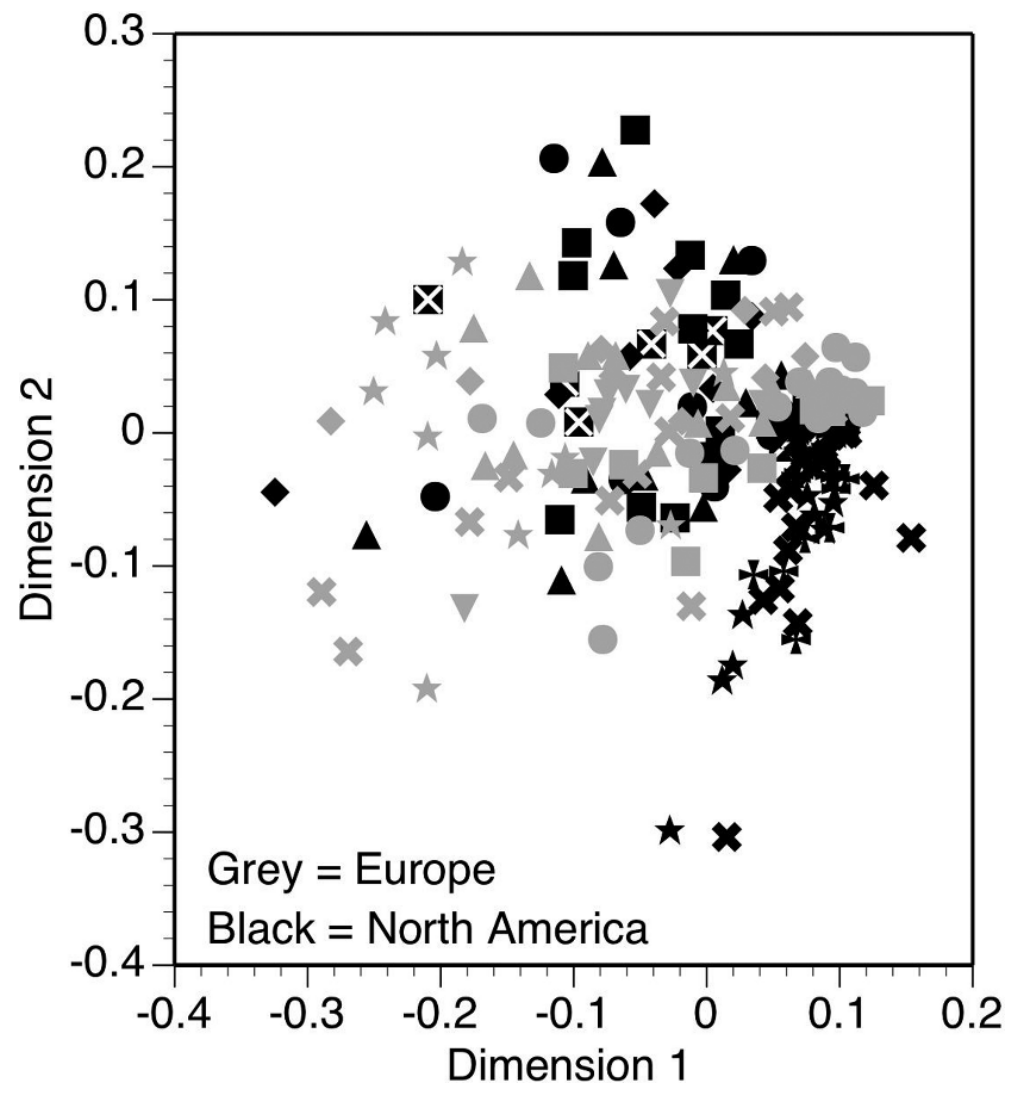

Fig. 12.1. Scatterplot of the first two dimensions of the matrix of 103 amplified fragment length polymorphic (AFLP ${ }^{\circledR}$ ) DNA markers scored on 205 reed canarygrass plants representing 15 cultivars, each cultivar represented by a different symbol (Data provided by M. D. Casler).

\subsection{Alfalfa}

\subsubsection{Botanical Description}

Alfalfa (Medicago sativa L.) is an important perennial forage legume and is considered a potential feedstock for production of renewable fuels (Samac et al. 2006). The United States produces the most alfalfa in the world with over 9.3 million hectares 
harvested in 2003 (USDA-NASS, Agricultural Statistics 2004) with California, South Dakota, and Wisconsin leading the way in production. Alfalfa can be grown from very cold northern plains to high mountain valleys, from rich temperate agricultural regions to Mediterranean climates. The lifespan of alfalfa ranges from 3 to 12 years, but most fields are harvested for only 4 years before fields are reestablished. Alfalfa is native to the Middle East, primarily Iran. It was introduced to the United States in the 1700's and 1800's and is now found throughout the continent (Russelle 2001). Cultivated alfalfa is a tetraploid $(2 n=4 x=32)$ with polysomic inheritance which complicates the genetic analysis required for mapping. Alfalfa has perfect flowers and is naturally cross-pollinated by bees, tolerates relatively little inbreeding, and can be vegetatively propagated by stem cuttings.

\subsubsection{Management and Bioprocessing}

Alfalfa can be sown in spring or fall, and grows best in fertile, well-drained soils at near neutral $\mathrm{pH}$. The deep root system and nitrogen-fixing ability with soil bacterium Sinorhizobium meliloti enables alfalfa to produce adequate yields under less than optimum soil moisture or nitrogen fertility. Some of the fixed nitrogen is returned to the soil for subsequent or companion crops (Samac et al. 2006). Alfalfa requires a great deal of potassium. Seeding rates are $13-20 \mathrm{~kg} \mathrm{ha}^{-1}$ in northern regions and a rate of $22 \mathrm{~kg} \mathrm{ha}^{-1}$ in the South. It is harvested two to three times a year and yields will vary from $3.4 \mathrm{Mg} \mathrm{ha}^{-1} \mathrm{yr}^{-1}$ dry matter (North Dakota) to $18.4 \mathrm{Mg} \mathrm{ha}^{-1} \mathrm{yr}^{-1}$ (Arizona) with an average of $7.8 \mathrm{Mg} \mathrm{ha}^{-1} \mathrm{yr}^{-1}$ (USDA-NASS, Agricultural Statistics 2004). Cultivation, harvesting and storing technologies are well established. Herbicides are used to control weeds and glyphosate-resistant alfalfa has been developed, but is not yet sold. Leaves and stems can be easily separated using shaking screens (Arinze et al. 2003). Leaves contain between 260 and $300 \mathrm{~g} \mathrm{~kg}^{-1}$ protein and are used as feed, whereas the stems, which contain $100-120 \mathrm{~g} \mathrm{~kg}^{-1}$ protein, would be considered the co-product for biofuels (Arinze et al. 2003). Leaf meal has been shown to be an excellent replacement of alfalfa hay or soybean meal for dairy cattle, and alfalfa leaves contain other secondary metabolites beneficial for human nutrition and food production (Samac et al. 2006).

\subsubsection{Genetics and Breeding}

The alfalfa flower is normally cross-pollinated by insects (McGregor 1976). For breeding purposes the perfect flowers have to be emasculated prior to pollination or, alternatively, male-sterile plants must be used as females. The flower must be tripped by moving the wing and keel pedals relative to the stigma, which releases the stamens and pistil. Numerous methods of crossing have been tried (Barnes and Stephenson 1971). Most alfalfa cultivars are synthetic cultivars. Individual plants with desirable genes are considered parents and are composited via replicated random mating (allowing all possible crosses with all possible parents) in isolation into the first-generation synthetic seed (Syn1). After a cultivar release, each further generation of seed increase of the synthetic is then done in isolation and random mating is assumed. Available diploid subspecies have been used for development of cultivated 
alfalfa as they are cross-fertile with cultivated alfalfa and have simplified the analyses required for developing diploid maps. The introgression of $M$. falcata into $M$. sativa increased the genetic variation and the range of adaptation of this crop to temperate climates of all continents (Rumbaugh et al. 1988). Nine highly diverse, distinct germplasm sources were introduced into North America from different regions of the world (Barnes et al. 1977). Nearly 3,200 Medicago accessions are listed in the NPGS, of which 950 are M. sativa (USDA-ARS, National Genetic Resources Program 2007).

Most of the improvements in alfalfa over the last decades have been in insectand disease resistance, improved ability to overwinter in cold climates, and fall dormancy. Disease resistance is important because it improves the usefulness of alfalfa on poorly drained soils, and during wet years. Fall dormancy is a major characteristic of alfalfa varieties. More dormant varieties have reduced growth in the fall, a response due to low temperatures and reduced day lengths. Non-dormant varieties exhibit winter growth activity, and are therefore grown in long-seasoned environments such as Mexico, Arizona, and Southern California, whereas dormant lines are grown in the Upper Midwest, Canada, and the Northeast.

Increases in overall alfalfa biomass yield would benefit the crop for use as a biofuel feedstock. Individual stem diameter is heritable and controlled by genes that act in an additive fashion (Volenec et al. 1987; Marquez-Ortiz et al. 1999). Genetic improvements for stem size and foliar disease resistance are reported to be present in European land races (Barnes et al. 1977). When comparing these biomass-type alfalfas to hay-type alfalfa under two management systems, the large-stem genotypes had $37 \%$ higher yield of cell wall polysaccharides than the forage hay genotypes and the theoretical potential ethanol yield doubled under a biomass management system (Lamb et al. 2007).

Generally, as stems mature, protein content decreases and carbohydrate content increases (Dien et al. 2006). At maturity, stems make up as much as $80 \%$ of the total dry matter and neutral detergent fiber (NDF), which generally estimates the percentage of total fiber (cellulose, hemicellulose and lignin) increases due to increases in xylem tissue (Jung and Engels 2002). The composition of the major cell wall polysaccharides and lignin has been studied extensively for different alfalfa maturity levels and under different growth environments (Samac et al. 2006). Although genetic differences in chemical composition of alfalfa stem cell walls have been small, there have been enough observable changes in genotypes selected for divergent contents of Klason lignin, cellulose and xylan (Lamb and Jung 2004) to conclude that cell wall compositions can be significantly changed through recurrent selection (Samac et al. 2006). Different pretreatment methods were performed on alfalfa fiber to maximize the release of fermentable sugars (Sreenath et al. 1999; Ferrer et al. 2002) for eventual conversion to ethanol (Sreenath et al. 2001). Alfalfa stems were reported to be more recalcitrant to dilute acid pretreatment than grasses (Dien et al. 2006), and syngas yields were reported to be greater during pyrolysis for alfalfa stems than for reed canarygrass or eastern gamagrass (Boateng et al. 2006).

Methods for genetic transformation of alfalfa have been developed and used to alter alfalfa for production of valuable co-products and improved digestion (Samac et al. 2006). Genetic maps of alfalfa have been published (Brummer et al. 1993; Kiss et 
al. 1993; Echt et al. 1994). The study of barrel medic (Medicago truncatula Gaertner) as a model species, which has a high degree of DNA sequence homology with alfalfa, has led to over 189,000 expressed sequence tags (ESTs), sequencing of thousands of unique genes, and mapping of genes that may be useful for the development of markers for cell wall conversion (Samac et al. 2006).

\subsubsection{Future Outlook for Alfalfa}

Alfalfa is grown widely throughout the United States and has potential for providing a dual crop consisting of a highly nutritious protein source from leaves for animal feed or human nutritional supplements and a stem fraction to be used as a source of fermentable sugars to produce ethanol. Unlike grasses, alfalfa can supply its own nitrogen and enrich the soil. Commercial production for biorefining has not yet been developed, however, and before this can become a reality, higher-yielding cultivars need to be developed.

\subsection{Wildrye}

\subsubsection{Botanical Description}

The cool-season $\mathrm{C}_{3}$ wild ryes are being considered as a potential bioenergy feedstock for the western United States (Larson - personal communication). Basin wildrye (Leymus cinereus (Scribn. \& Merr.) Á. Löve) is the largest native perennial grass in the Rocky Mountain and Intermountain regions, and the larger giant wildrye ( $L$. condensatus (C. Presl) Á. Löve) is native to California (Dewey 1984). Basin wild rye grows in large vigorous stands in lush, high-mountain valleys, riparian areas, foothills, and hollows, but also grows on some of the harshest sites in the Great Basin region. It grows from British Columbia south to the east of the Sierra Nevada in California and eastward throughout the Intermountain and Rocky Mountain regions to eastern portions of Montana, Wyoming, and Colorado (Barkworth and Atkins 1984). Another closely related but morphologically divergent species, beardless wildrye Leymus triticoides (Buckley) Pilg., has aggressive rhizomes, is adapted to harsh, cold and desert climates and ranks among the most salt-tolerant grasses of the world. Optimal growth occurs on silt and clay soils, but the wildryes are also tolerant of sandy textured soil (Wasser 1982). The wildryes are adapted to mean annual precipitation zones of 25-50 cm (Wasser 1982) and grow at elevations of 300-2,750 m. They hold potential as an alternative crop for many irrigation systems challenged by salinity and declining water supplies in the western United States (Larson et al. 2006). The species are naturally outcrossed and highly self-sterile (Jensen et al. 1990). The basic Leymus genome is composed of seven chromosomes (Dewey 1984). More than half of $L$. cinereus are allotetraploid $(2 n=4 x=28)$; octoploids and dodecaploids also occur (Larson et al. 2006). 


\subsubsection{Management and Bioprocessing}

Leymus species are propagated by seed and established in the early spring or late fall (Alderson and Sharpe 1994). They are planted with a disc or deep furrow drill to a depth of $0.5-2 \mathrm{~cm}$ in fine-textured soils at between 5 and $7 \mathrm{~kg} \mathrm{ha}^{-1}$. Bromoxynil may be necessary to suppress broadleaf weeds during establishment. They are most often grazed or cut for hay after the second year of establishment. Yields of 3-20 Mg ha have been reported for the various species from tests ranging from New Mexico north to Canada, and west to Idaho, Utah, and California (Jefferson et al. 2002; 2004; Lauriault et al. 2005; Benes et al. 2005) with minimal input and relatively unimproved germplasm. Released cultivars of basin wild rye include 'Magnar' and 'Trailhead' with other improved germplasm being released (USDA-NRCS 1998). Management procedures have yet to be developed for bioprocessing.

\subsubsection{Genetics and Breeding}

The main benefits of wildryes for biofuels are the yield potential of the crop in the western and intermountain regions, their potential for improvement through interspecific crossing and their close relationship to both wheat and barley. The sodforming $L$. triticoides has been observed growing in close proximity to L. cinereus at disturbed sites, but separated under natural circumstances based on adaptability (Larson et al. 2006). $F_{1}$ hybrids derived from some initial crosses of these two species were very robust and showed an extremely heterotic combination $\mathrm{f}$ tall plant height (some greater than $2 \mathrm{~m}$ ), large stems and leaves from L. cinereus and a vigorous proliferation of tillers and rhizomes from $L$. triticoides (Larson - personal communication).

Genetic maps of this hybrid are being developed and relevant traits are being identified with QTL (Wu et al. 2003; Larson et al. 2006; Larson and Mayland 2007). Molecular genetic maps were constructed for two full-sib Leymus populations, TTC1 (164 clones) and TTC2 (170 clones), and QTL were identified that control numerous traits including plant height, rhizome proliferation, flowering, seed shattering, seed germination, salt tolerance, NDF (total fiber content), acid detergent fiber (ADF; estimates cellulose and lignin), crude protein, and virtually all of the macro- and micro-minerals (Larson et al. 2006; Larson and Mayland 2007). Several strong NDF and ADF QTL showed good homology between the mapping populations based on early spring forage. Current Leymus molecular resources come from L. chinensis (Jin et al. 2006) and L. cinereus and include over 11,000 ESTs which identified 300 SSRs, and a $5 \times$ BAC library (Larson, unpublished). Useful genetic stocks include two independent sets of wheat-mammoth wildrye (Leymus racemosus (Lam.) Tzvelev) chromosome addition/substitution lines, which provide a valuable resource for genetic and physical mapping (Qi et al. 1997; Kishii et al. 2004).

\subsubsection{Future Outlook for Wildrye}

The potential of the wildryes as a biofuel feedstock is primarily restricted to the mountain and intermountain areas of the western United States where other species 
are not well adapted. There is a great deal of genetic variability available through intra- and inter-specific breeding and efforts on molecular mapping of the genus are well underway. Management and bio-processing methods will need to be developed, and the yield potential needs to increase to enable concentrated production for an energy-producing facility.

\subsection{Big Bluestem}

\subsubsection{Botanical Description}

Big bluestem (Andropogon gerardii Vitman), a single species, belongs to the subfamily Panicoideae and tribe Adropogoneae. A race known as sand bluestem (sometimes referred to as $A$. hallii Hack) is occasionally reported in the literature. It is distinguished by the presence of extensive rhizomes which are truncated in big bluestem. Researchers have shown that cross pollination of sand and big bluestem is possible and the progeny are completely fertile (Peters and Newell 1961), indicating a single species.

Big bluestem is a warm-season $\left(\mathrm{C}_{4}\right)$, perennial, native grass that once dominated the tall-grass prairie of North America (Weaver 1968; Gould and Shaw 1983). A bunch-type grass reaching 1-3 $\mathrm{m}$ in height depending on water and nutrient availability, the plant develops deep roots (Stubbendieck et al. 1991). Root depths are reported to be $1.3 \mathrm{~m}$ during the establishment year, up to $2.7 \mathrm{~m}$ once established. Among the most dominant features of big bluestem are its short, tough rhizomes (contrasting it with the individuals identified as sand bluestem). While big/sand bluestem can be propagated by crown divisions, most large-area establishment is from seed. It is considered a late successional grass that grows best in and tends to dominate rich, sandy soils, but also persist on sandy or clay loams (Weaver 1968). The original range of big bluestem is reported to be similar to switchgrass (Panicum virgatum L.; see Chapter 11) from central Mexico north to Canada (Gould and Shaw 1983). This wide north-to-south range causes substantial variation in duration of growing season depending on plant origin. Photoperiod governs onset and cessation of growth and flowering. It is considered a short-day plant, with jointing and flowering initiated by decreasing day length in late summer. Photoperiod strongly governs growth. Moving individuals from southern areas to more northerly locations causes southern individuals to remain actively growing later into the shorter season than those individuals from populations native to that area. Conversely, northern populations moved farther south will cease to grow early in the growing season, even though conditions remain suitable for growth (Newell 1968; Waller and Lewis 1979).

Big bluestem has a base chromosome number of 10 (Gould 1968), with two cytotypes: hexaploid $(2 n=6 x=60)$ and enneaploid $(2 n=9 x=90)$ (Norrmann et al. 1997). While enneaploids exist in the wild, examination of ten widely used cultivars has determined all to be hexaploid (Riley and Vogel 1982; Vogel 2000). Populations of big bluestem depend on cross pollination by wind for seed production. Controlled self-pollinations of big bluestem result in less than $5 \%$ seed set. Seed production 
under the best conditions is limited to about $50-60 \%$ of the visible florets (Norrmann et al. 1997).

\subsubsection{Management and Bioprocessing}

Like most of the North-American native species, big bluestem is notoriously slow to establish from seed. Seedlings are often overlooked in a field during establishment because of the dominance of annual grassy weeds. Conventional wisdom would suggest that ideal planting should occur in the spring to allow maximum growth during that first year. However, soil temperature for ideal growth is $25^{\circ} \mathrm{C}$ (Hsu et al. 1985; Delucia et al. 1992), indicating a slight delay in planting coupled with a timely broad spectrum herbicide application may be more desirable. Maximum biomass production of big bluestem is not achieved until 3-4 years after sowing. The increased yield is derived from culms arising from the rhizome growth of the crown. Spring burning of the first-year crop and residual weedy chaff may be useful in increasing subsequent growth and biomass yield. Burning big bluestem in early or late spring can increase forage production by $52-70 \%$, respectively, over unburned control plots (Mitchell et al. 1994).

Big bluestem is considered to be good forage for all livestock, especially early in the growing season when the plant biomass consists predominantly of leaves (Redfearn and Nelson 2003). While considered nutritious during spring and summer, it becomes less digestible as stem elongation commences during the onset of flowering during late summer.

As a grass species, big/sand bluestem shows potential for biofuel. This species has shown greater in vitro fermentability than other warm-season grass species (Jung and Vogel 1992). As a result, potential for production of ethanol and value-added chemicals via consolidated bioprocessing (a direct fermentation process; see Chapter 6) may offer this species a distinct advantage over acid hydrolysis, saccharification and fermentation of switchgrass (Weimer and Springer 2007). Cost of production is also a factor when determining feasibility of a biofuel crop. When analyzing cost of production of big bluestem and switchgrass for yield and economic feasibility from a biofuel perspective; switchgrass was faster to establish, but by the second year, big bluestem became the most productive species. Comparing cost of processing for biooil, big bluestem was determined to be less expensive than switchgrass and produced more bio-oil from pyrolysis. The returns on investment from big bluestem (US\$19.38 $\mathrm{Mg}^{-1}$ ) also exceeded switchgrass (US\$10.47 $\mathrm{Mg}^{-1}$ ) (Tiffany et al. 2006). Cost of biomass production can vary by location. In Iowa, cost of production of big bluestem was intermediate to switchgrass - the least expensive to produce - and alfalfa or reed canarygrass, which were the most expensive (Hallam et al. 2001).

\subsubsection{Genetics and Breeding}

The past and indeed, current breeding of native species of North America, is focused on improved cultivars selected primarily for increased forage/nutritional value for grazing (Mitchell et al. 2003; 2005 Vogel and Mitchell 2003; Vogel et al. 2006a;b). Although big bluestem was once the dominant species on the Great Plains (Weaver 
1968; Gould and Shaw 1983), most of that area was plowed up and converted to row crops during the 19th century westward population expansion of the U.S. Remnant stands, occurring in cemeteries, along railroad right-of-ways and other fallow areas, can be exploited for their genetic diversity. Germplasm collections of big bluestem were extensive in the 1970's at many of the Plant Materials Centers (PMC) of the U.S. Natural Resources Conservation Service (NRCS) and Plant Introduction Centers of ARS. Fiscal constraints have caused many of these collections to be plowed under. However, relatively large big bluestem resources for the south-central and southeastern U.S. are located at Elsberry Plant Materials Center (Elsberry, MO) and at the USDA-NRCS Jimmy Carter Plant Materials Center (Americus, GA), respectively. There are 450 accessions of big bluestem collected from native stands throughout the southeast at Americus and 370 accessions from the south-central U.S. at Elsberry. A smaller collection still exists at Rose Lake PMC (East Lansing, MI) containing 106 accessions from southern Indiana to northern Michigan.

Gametophytic self-incompatibility in big bluestem makes cross pollination the rule (Norrmann et al. 1997), thus enhancing genetic variability of the species. Classical breeding techniques take advantage of this incompatibility to produce crosses among groups of desirable genotypes by isolating them from others. Isolation can come from actual pollen containment via bags of various sizes or by physical distance from native stands. The polyploid nature of the species also serves to retain substantial genetic variability. Unlike switchgrass, in which the cytotypes are genetically isolated from one another (Martínez-Reyna and Vogel 2002; see also Chapter 11), big bluestem cytotypes freely crosspollinate. This generates viable aneuploid individuals from the native hexa- and enneaploid populations (Norrmann et al. 1997; Norrmann and Keeler 2003). Such pollen transfer indicates gene flow is occurring from each group, suggesting a single species.

Big bluestem can be vegetatively propagated from crown divisions or rhizome cuttings, allowing collection and clonal propagation of new germplasm without destruction of the existing stand. While classical breeding strategies are useful in big bluestem improvement, the recalcitrant nature of seed germination and seedling survival challenges progress.

There are a limited number of improved varieties available on the market. Some selections of big bluestem that have been released were derived from limited parental base, but most improved cultivars are generally synthetic composites of 20-60 mother plants selected for their improved characteristic and propagated one to three generations (Vogel et al. 2006a,b). Examples of big bluestem cultivars (and location of release) include: 'Bison' (ND); 'Bonilla' (SD); 'Niagara' (NY); 'Rountree' (IA); 'Champ' (NE/IA); 'Pawnee', 'Goldstrike', 'Goldmine', 'Bonanza' (NE); 'Kaw' (KS); 'Earl' and 'Chet' (TX).

\subsubsection{Future Outlook for Big Bluestem}

Difficulty in planting and establishment of big bluestem limits its wide acceptance. Seed requires processing to remove hairs or specialty drills to be planted. Other issues that limit big bluestems as a biofuel feedstock center around weed control. Enhanced weed control, especially of annual grasses, might allow sufficient big 
bluestem establishment to warrant fertilizer application during the first year, further enhancing first-year yield. Cultivar testing over larger and additional areas is needed. Management schemes need to be devised to exploit maturity similar to those used in the southern U.S. with soybean. It might be desirable to plant an early maturing (northern) cultivar at a southern location. While a producer might compromise yield to some extent, he/she would be able to harvest earlier in the season, but after the crop had gone dormant. Research indicates that delayed harvest of standing grasses offers a substantial advantage in terms of biofuel quality, i.e. reduction of ash, sulfur, phosphate, and nitrogen compounds (Muir et al. 2001; Baldwin and Cossar 2005; Cassida et al. 2005; Adler et al. 2006). Standability (ability to remain erect into the winter) then becomes a vital concern. Variation for erectness is present in big bluestem and selection for individuals that resist late season lodging would also be desirable.

Two factors may make the biggest difference in big bluestem's increased production area. The first is that this species produces twice the biomass per unit of applied nitrogen than either switchgrass or indiangrass (Sorghastrum nutans (L.) Nash) (Perry and Baltensperger 1979). With the costs of nitrogen fertilizer increasing, it seems nitrogen use efficiency will become increasingly important. Second, preliminary research utilizing consolidated bioprocessing (Weimer and Springer 2007) indicates that big bluestem is a superior feedstock, and may offer accelerated development for big bluestem in the biofuels arena. The fact that big bluestem is endemic to North America also works in its favor when considering expanding the production area in the U.S.

\subsection{Bermudagrass}

\subsubsection{Botanical Description}

Bermudagrass and stargrass consist of a number of species under the genus Cynodon that are geographically widely distributed throughout the world but that occur most abundantly in tropical and sub-tropical regions of Africa to Southeast Asia where they most likely originated (Taliaferro et al. 2004). They are perennial in nature and go through a winter dormancy period. Cynodon taxonomy was most recently revised by Harlan et al. (1970a). In regard to potential use as feedstocks for bioenergy, the widely adapted and variable bermudagrass forage genotypes within $C$. dactylon (L.) Pers. var. dactylon and the highly productive coarse stargrass ( $C$. nlemfuënsis Vanderyst var. nlemfuënsis) are the primary species used in selection programs, but, desirable traits may exist among the other species. Bermudagrass possess rhizomes and the taxon is highly variable, being further characterized into three major races by Harlan and de Wet (1969). They distinguish the tropical and temperate races by their adaptation characteristics, where the temperate race is much more winter hardy. The seleucidus race has a greater potential of contributing genes for higher biomass due to the coarse robust growth habit and cold tolerance. 
The bermudagrass taxa exist in tropical regions to as far north as the $53^{\circ} \mathrm{N}$ lat and at elevations from sea level to 3,000 m (Harlan and de Wet 1969), whereas stargrasses are more limited to tropical or semi-tropical regions that do not reach temperatures below $-6^{\circ} \mathrm{C}$ (Mislevy et al. 1989a;b). One of the factors contributing to the lack of cold tolerance in stargrass is the fact that most genotypes lack rhizomes.

The introduction of bermudagrass to the New World most likely occurred soon after the arrival of Columbus and spread throughout southern Colonial America and became an important pasture grass in the early 19th century (Burton and Hanna 1995). Plant collections have been made from northern climates as far north as Michigan, but the most productive and persistent genotypes remain in the southern United States. The first collections of stargrass were reported for use in crossing and selection in the 1930's (Burton 1951). The poor freeze tolerance of stargrass limits its use to the southern part of Florida, but it is very important to Central and South America (between $23^{\circ} \mathrm{N}$ and $23^{\circ} \mathrm{S}$ and elevation of $<5,000 \mathrm{~m}$ ). Most species are relatively drought tolerant (Burton et al. 1954), but require at least $500 \mathrm{~mm} \mathrm{yr}^{-1}$ rainfall for persistence and good production.

The base chromosome number of $x=9$ has been confirmed (Forbes and Burton 1963; Harlan et al. 1970b). The species are primarily diploid or tetraploid in nature, with just a few hexaploids reported (Taliaferro et al. 2004). Hybridization among parents of different ploidy levels produces triploids and pentaploids (Taliaferro et al. 2004; Anderson 2005). Species of the genus Cynodon have perfect flowers and are generally considered to be outcrossing due to self-incompatibility (Burton and Hart 1967). Flowers bear one pistil and three anthers. Self-compatibility has ranged from 0.5 to $10 \%$ in various studies (Taliaferro et al. 2004), but a few genotypes within the core collection (Anderson 2005) were observed to have high levels of selfed seed (unpublished data). Successful production of hybrid cultivars are generally attributed to the cross pollinating nature of the taxa.

\subsubsection{Management and Bioprocessing}

Most improved hybrid bermudagrass cultivars are propagated vegetatively using socalled sprigs, which consist of roots, stems, stolons and/or rhizomes. This allows for clonal maintenance of the hybrids and takes advantage of hybrid vigor (Burton 1956). Methods of establishing sprigged bermudagrass were established in the 1950's and remain relatively unchanged (Taliaferro et al. 2004). There are also some seeded cultivars that can be sown by drilling or broadcasting (Taliaferro et al. 2004). Once established, bermudagrass pastures have been known to persist for decades, especially clonally propagated hybrids such as 'Coastal' (Burton 1948), which was first developed in 1943 and which is found on many pastures in the Southern U.S. today.

In order for bermudagrass to be established successfully by sprigs or seed, it is important to minimize weeds and to supply the stand with adequate nutrients. While there are only a limited number of herbicides available for pastures, some phenoxy herbicides can control broadleaf weeds, whereas others have been developed to control sedges and crabgrass (Taliaferro et al. 2004). Bermudagrass and stargrass require a relatively high nutrient availability for high yields. Most of the studies on nutrient 
requirements were conducted in the 1940's and 1950's on the cultivar 'Coastal'. From these studies a recommendation of up to $448 \mathrm{~kg}(\mathrm{~N}) \mathrm{ha}^{-1}$ and a ratio of 4-1-2 to 4-1-4 N- $\mathrm{P}_{2} \mathrm{O}_{5}-\mathrm{K}_{2} \mathrm{O}$ should be applied on sandy loam soils with a $\mathrm{pH}$ of at least 5.5 (Taliaferro et al. 2004).

Although bermudagrass is a major pasture for the Southern U.S., millions of hectares are harvested as hay. Methods for cutting, drying and packaging biomass are well established and are reviewed by Taliaferro et al. (2004). Varieties, clipping rates, and climate all affect the quality of the hay for livestock feed. For high-quality hay, bermudagrass and stargrass are recommended to be cut every 4-5 weeks, when digestibility is high and crude protein production is maximized. Biomass yields, however, increase with longer intervals (Burton et al. 1963). Some of the quality parameters, such as NDF, ADF and dry matter digestibility (DMD), are negatively affected by rain, high humidity and maturity of the hay. These genetic and management effects will likely affect conversion efficiency of the cell wall to sugars for fermentation as well. Rumen dry matter digestibility is considered to be a good predictor of conversion efficiency to sugars used for fermentation to ethanol due to the similarity in the types of enzymes used to break down the cell wall components.

Though 'Common' bermudagrass from selection of naturally occurring biotypes was utilized as a forage grass throughout the 19th and into the 20th century, no extensive breeding efforts were started until the 1930's. The first major bermudagrass cultivar to be developed was 'Coastal' (Burton 1948). Many sprigged and seeded cultivars have been developed and released since then. The cultivars were released based on improvements in yield, cold tolerance, rumen digestibility or adaptability to soil or water constraints (Taliaferro et al. 2004). More recent releases of 'Tifton 85' (Burton et al. 1993) and 'Midland 99' (Taliaferro et al. 2002) have raised the bar on yield, forage quality and adaptability. Yields will vary depending upon location, climate, soil conditions and management. Yields in the eastern U.S. tend to be higher (Table 12.1). In a comparison with 'Alamo' switchgrass and 'Merkeron' napiergrass, 'Tifton $85^{\prime}$ ' bermudagrass produced more dry biomass than switchgrass over a 6-year period at three locations in Georgia (Table 12.2) (Bouton 2002). The plants in this test were fertilized twice with $34 \mathrm{~kg} \mathrm{~N} \mathrm{ha}^{-1}$ and harvested in mid and late summer. The high biomass production potential of bermudagrass is offset by the reliance on high fertility (primarily $\mathrm{N}$ and $\mathrm{K}$ ) and high soil moisture. The crop is tolerant of long periods of drought, however, and is very persistent.

\subsubsection{Genetics and Breeding}

Early efforts in breeding of bermudagrass were directed at developing superior clonally propagated $\mathrm{F}_{1}$ hybrids. This was performed by controlled crosses, utilizing the strong self-incompatibility of bermudagrass plants. Parental lines were planted in close proximity in isolated field plots or by placing detached floriferous shoots of respective plants together in a container of water, isolated from other plants (Taliaferro et al. 2004). Full-sib seed from mutual pollination were then planted and selected plants were clonally propagated for testing or used for subsequent crosses. Breeding for seeded varieties requires characterization of potential clonal parental lines for inflorescence characteristics that allow for proper inflorescence maturity for 
sufficient out-crossing to produce seed. Multiple parents may be used to develop synthetics in isolated open-pollinated nurseries.

Table 12.1. Average yields ( $\mathrm{Mg}$ dry matter $\mathrm{ha}^{-1}$ ) over years of selected bermudagrass cultivars tested in the southern United States

\begin{tabular}{|c|c|c|c|c|c|}
\hline Location & Years & & Cultivars & & \\
\hline & & Coastal & Tifton 85 & Russell & Midland 99 \\
\hline${ }^{\mathrm{a}}$ Overton, TX & 1997-2002 & 7.81 & 12.04 & & \\
\hline${ }^{\mathrm{b}}$ Raymond, MS & 1995-1999 & 8.33 & 9.79 & & \\
\hline${ }^{\mathrm{b}}$ Newton, MS & 1995-1999 & 9.23 & 9.54 & & \\
\hline${ }^{\mathrm{c}}$ Ardmore, OK & $1996-2003$ & 9.49 & 10.12 & 8.76 & 8.96 \\
\hline${ }^{\mathrm{d}}$ Fairhope, AL (irrig.) & $2005-2006$ & 16.50 & 23.26 & 14.82 & \\
\hline${ }^{\mathrm{d}}$ Fairhope, AL (dry) & 2005-2006 & 13.75 & 22.14 & 13.81 & \\
\hline${ }^{\mathrm{e}}$ Tifton, GA & 2003-2005 & 16.11 & 19.37 & 19.34 & \\
\hline${ }^{\mathrm{e}}$ Calhoun, GA & 2003-2005 & 17.93 & 25.00 & 21.91 & \\
\hline${ }^{\mathrm{e}}$ Griffin, GA & 2003-2005 & 16.38 & 18.38 & 18.55 & \\
\hline${ }^{\mathrm{f}}$ Shorter, AL & 1992-1994 & 21.89 & 22.69 & 22.90 & \\
\hline
\end{tabular}

Data courtesy of the following sources:

${ }^{a}$ Gerald W. Evers, Texas A\&M Univ. Agricultural Research and Extension Center, Overton, Texas (from Proceedings Amer. Forage and Grass. Conf., 2001, Arkansas)

${ }^{b}$ Mississippi Forage Crop Variety Trials Information Bulletin 356, 1999

'Jerrry L. Baker - NF21 Forage Yields 2003 at Noble Foundation, Ardmore, OK

${ }^{\mathrm{d}}$ Personal communication - Mike Davis, Auburn University

${ }^{\mathrm{e} J o h n ~ A n d r a e ~-~ D e p t . ~ o f ~ E n t o m o l o g y, ~ C l e m s o n ~ U n i v e r s i t y ~}$

${ }_{\mathrm{f}}^{\mathrm{http}} / / / \mathrm{www}$.aces.edu/dept/forages/bermudagrass/russell_bermuda.htm

Vogel and Jung (2001) presented strategies to modify plants for the optimal use as feedstocks for biofuels. They state that besides traits such as cellulose and lignin concentration, other traits that affect recalcitrance be determined. Reduction in recalcitrance has historically been measured by digestion of dry matter by ruminant microbes for improving forage quality. Breeding for improved quality for forages, as defined as increased animal production per unit dry matter, began in the 1960's. This became possible when in vitro laboratory techniques were devised to improve efficiency of evaluating material for forage quality (Tilley and Terry 1963; Monson et al. 1969). Broad sense heritability $\left(\mathrm{h}^{2}\right)$ estimates for in vitro dry matter digestibility (IVDMD) ranged from 0.27 to 0.69 (Burton and Monson 1972) and breeding efforts resulted in a number of cultivars with improved forage quality (Burton 1972; Taliaferro and Richardson 1980; Burton and Monson 1984; 1988; Eichhorn et al. 1986; Burton et al. 1993).

The first bermudagrass forage with improved quality, 'Coastcross-1' (Burton 1972), was a hybrid derived from a cross between 'Coastal' and a C. nlemfuënsis var. robustus (Harlan et al. 1970a) plant introduction from Kenya. The changes in bio- 
degradation of specific cell wall types between 'Coastcross-1' (CC 1) and 'Coastal' were studied via histochemical techniques (Akin et al. 1990). They reported that the parenchyma bundle sheaths of CC 1 displayed less UV absorbance, indicative of lower levels of phenolic acid esters than in 'Coastal'. This suggested that reduced levels of these compounds contributed to improved cell wall degradation. In another highly digestible cultivar, 'Tifton 85 ' (Burton et al. 1993), the ratio of ether- to esterlinked phenolic acids was lowered, resulting in improved bioconversion (Mandebvu et al. 1999a;b). Despite the higher cell wall content (as evidenced by the higher NDF and ADF values) of 'Tifton 85' bermudagrass relative to 'Coastal', the cell wall of 'Tifton 85 ' was more digestible. The concentration of esterified ferulic acid was similar for 3- and 6-week old 'Tifton 85 ' (11.6 and $10.0 \mathrm{~g} \mathrm{~kg}^{-1}$, respectively) and 'Coastal' (10.6 and $10.6 \mathrm{~g} \mathrm{~kg}^{-1}$, respectively), but the concentration of etherified ferulic acid was lower for 'Tifton 85 ' (6.2 and $4.9 \mathrm{~g} \mathrm{~kg}^{-1}$, respectively) than for Coastal (8.1 and $7.6 \mathrm{~g} \mathrm{~kg}^{-1}$, respectively) (Mandebvu et al. 1999b). In a similar study, Hatfield et al. (1997) concluded that the higher digestibility of 'Tifton 85' over 'Coastal' bermudagrass was due to lower lignin content and lower levels of cross-linked polysaccharides resulting from the lower levels of ether-linked ferulates.

Table 12.2. Yields of 'Tifton 85 ' bermudagrass, 'Alamo' switchgrass, and 'Merkeron' napiergrass at three locations in Georgia from 1996 to 2001 (Mg dry matter ha ${ }^{-1}$ ). From: Final Report for 1996-2001; Bioenergy Crop Breeding and Production Research in the Southeast, ORNL/SUB-02-19XSV810C/01 (J.H. Bouton, University of Georgia)

\begin{tabular}{lrrrrrrr}
\hline & 1996 & 1997 & 1998 & 1999 & 2000 & 2001 & Average \\
\hline Athens & & & & & & & \\
Bermudagrass (Tifton 85) & 9.3 & 24.9 & 16.6 & 13.9 & 18.5 & 22.6 & 17.6 \\
Switchgrass (Alamo) & 6.7 & 21.4 & 16.6 & 19.0 & 11.0 & 22.1 & 16.1 \\
Napiergrass (Merkeron) & 23.8 & 32.1 & 33.6 & 39.6 & 19.2 & 16.3 & 27.5 \\
Tifton & & & & & & & \\
Bermudagrass (Tifton 85) & 9.9 & 15.8 & 24.3 & 15.5 & 19.2 & 20.4 & 17.5 \\
Switchgrass (Alamo) & 6.3 & 13.8 & 21.6 & 17.7 & 16.6 & 21.8 & 16.3 \\
Napiergrass (Merkeron) & 41.6 & 30.8 & 39.8 & 17.9 & 24.9 & 13.3 & 28.1 \\
Midville & & & & & & & \\
Bermudagrass (Tifton 85) & & 11.8 & 24.2 & 22.1 & 12.5 & 17.2 & 17.6 \\
Switchgrass (Alamo) & & 6.8 & 15.4 & 17.7 & 4.2 & 13.1 & 11.5 \\
Napiergrass (Merkeron) & & 20.1 & 48.9 & 45.9 & 20.1 & 18.6 & 25.6 \\
\hline LSD (5\%) for Midville & & 2.0 & 5.0 & 5.2 & 3.0 & 4.2 & \\
\hline
\end{tabular}

Recently studies have been conducted to evaluate some of the released cultivars for bio-conversion using enzymatic hydrolysis with ferulic-acid esterase and cellulases. One study did not reveal significant differences between genotypes in the amounts of phenolic acids (Anderson et al. 2005), but a second study supported that 'Tifton 85' has higher levels of ester-linked phenolic acids than either 'Coastal' or 'Coastcross II' (CCII) (Anderson et al. 2008). The data suggest that the superior 
forage quality of the 'Coastcross' lines and 'Tifton 85 ' translate into higher conversion efficiency to sugars and ultimately to ethanol. It appears, however that different genes are involved in the reduction of recalcitrance for these two bermudagrass cultivars. The 'Coastcross' lines have lower levels of phenolic acid esters in the parenchyma bundle sheaths than 'Coastal', whereas 'Tifton 85 ' appears to have more ester-bound phenolic acids that are more easily released with esterases.

Though the USDA-NPGS maintains 328 accessions (USDA-ARS, National Genetic Resources Program 2007), the largest known collections of diverse Cynodon germplasm are found at Oklahoma State University (Stillwater, OK) and the USDAARS breeding program in Tifton, GA. Oklahoma State University has had an active bermudagrass breeding program and currently maintains over 700 accessions that includes plant introductions from around the world, current cultivars and breeding lines (Yanqi $\mathrm{Wu}$ - personal communication). The USDA-ARS forage breeding program at Tifton, GA maintains over 700 accessions, most of which originated from African collections (Taliaferro et al. 2004). The collection began with collection trips in the 1930's and also includes past and present breeding lines. From the full Tifton collection a very diverse forage bermudagrass core collection with 175 plant introductions was developed through phenotypic and ploidy level evaluations (Anderson 2005). This collection has been analyzed for fiber components and IVDMD (Anderson 2006). There was significant variation among entries for IVDMD (483-710 g $\mathrm{kg}^{-1}$ ), NDF (643-773 $\mathrm{g} \mathrm{kg}^{-1}$ ) and acid detergent fiber ADF (241-345 $\mathrm{g} \mathrm{kg}^{-1}$ ). IVDMD was negatively correlated with $\mathrm{NDF}\left(\mathrm{R}^{2}=-0.86\right)$ and $\mathrm{ADF}\left(\mathrm{R}^{2}=-0.58\right)$. ADF and NDF were correlated $\left(\mathrm{R}^{2}=0.71\right)$, but entries such as 'Tifton 68 ' had very high digestibility despite moderately high NDF and ADF. A smaller but diverse group of entries was selected from within the core collection for evaluation of biomass-to-ethanol conversion using a dilute-acid pretreatment followed by simultaneous saccharification and fermentation (SSF). The 50 bermudagrass lines varied for both ethanol production (105-167 $\mathrm{mg} \mathrm{g}^{-1} \mathrm{DM}$ ) and pentose released (133-222 $\mathrm{mg} \mathrm{g}^{-}$ $\left.{ }^{1} \mathrm{DM}\right)$. The common bermudagrass cultivars produced more ethanol but less pentose sugars than the switchgrass control (Table 12.3).

Table 12.3. Ethanol production and pentose residue of bermudagrass and switchgrass after dilute acid hydrolysis and simultaneous saccharification and fermentation (SSF) with yeast strain Saccharomyces cerevisiae D5A. Data courteously supplied by Bruce Dien (USDAARS, Peoria, IL)

\begin{tabular}{lcc}
\hline Entry & Ethanol production $[\mathrm{mg} / \mathrm{g}]^{1}$ & ${\text { Pentose residue }[\mathrm{mg} / \mathrm{g}]^{\mathbf{1}}}^{\mathbf{1}}$ \\
\hline Tifton 85 & $159.7 \mathrm{a}$ & $182.8 \mathrm{c}$ \\
Coastcross II & $156.5 \mathrm{a}$ & $198.8 \mathrm{~b}$ \\
Coastal & $145.9 \mathrm{~b}$ & $171.0 \mathrm{~d}$ \\
\hline Switchgrass & $116.2 \mathrm{c}$ & $206.3 \mathrm{a}$ \\
\hline
\end{tabular}

${ }^{1}$ Means with the same letter are not significantly different $(\alpha=0.05)$

When compared with other potential bioenergy feedstock grasses, bermudagrass had higher conversion efficiency to ethanol. Using dilute-acid pretreatment followed by SSF (Anderson et al. 2008), bermudagrass produced more ethanol than a midmaturity switchgrass check (Table 12.3) and more than either napiergrass (Pennise- 
tum purpureum) or giant reed (Arundo donax) (Table 12.4). It is important to note that the bermudagrass lines 'Coastal' and 'Tifton 85' were sampled at 12 weeks, which is past the prime harvest period of 4-6 weeks that ensures the best forage quality, yet it resulted in more ethanol than the tall bunch grasses. In addition, it is noteworthy that in contrast to what was observed for the bunch grasses, bermudagrass stem and leaf tissue converted equally well (Table 12.4).

Very little research has been conducted to determine genetic differences of the forage grasses for thermo-chemical conversion of biomass to energy. Thermochemical procedures involve gasification followed by either biological or catalytic conversion of the resultant synthesis gas to methanol and/or ethanol. This process may be more flexible with respect to feedstock, and may provide higher ethanol yields per ton $(>4001)$ than the hydrolysis-based procedures, and at lower costs $\left(<\mathrm{US} \$ 0.25 \mathrm{1}^{-1}\right)$ than corn ethanol (Bransby 2006). One study indicated that there is no difference between leaf and stems of 'Coastal' and 'Tifton 85' bermudagrass for production of syngas (Boateng et al. 2007).

Table 12.4. In vitro dry matter digestibility (IVDMD), neutral detergent fiber (NDF), acid detergent fiber (ADF), acid detergent lignin (ADL) and ethanol production of leaf and stem tissues of 12-week old bermudagrass (Cynodon sp.), mature napiergrass (Pennisetum purpureum) and giant reed (Arundo donax) grown at Tifton, GA. 2004. Adapted from Anderson et al. (2008)

\begin{tabular}{llllllll}
\hline Species & Genotype & Tissue & $\begin{array}{l}\text { IVDMD }^{1} \\
{[\%]}\end{array}$ & $\begin{array}{l}\mathrm{NDF}^{1} \\
{[\%]}\end{array}$ & $\begin{array}{l}\mathrm{ADF}^{1} \\
{[\%]}\end{array}$ & $\begin{array}{l}\mathrm{ADL}^{1} \\
{[\%]}\end{array}$ & $\begin{array}{l}\text { Ethanol } \\
{[\mathrm{mg} / \mathrm{g}]^{1}}\end{array}$ \\
\hline $\begin{array}{l}\text { Cynodon } \\
\text { sp. }\end{array}$ & Tifton 85 & Leaf & $47.1 \mathrm{c}$ & $77.6 \mathrm{~g}$ & $35.0 \mathrm{abc}$ & $2.93 \mathrm{a}$ & $139.6 \mathrm{a}$ \\
$\begin{array}{l}\text { Cynodon } \\
\text { sp. }\end{array}$ & Tifton 85 & Stem & $49.2 \mathrm{c}$ & $77.5 \mathrm{~g}$ & $37.2 \mathrm{~cd}$ & $4.04 \mathrm{~b}$ & $141.1 \mathrm{a}$ \\
$\begin{array}{l}\text { Cynodon } \\
\text { dactylon. }\end{array}$ & Coastal & Leaf & $35.4 \mathrm{e}$ & $77.0 \mathrm{fg}$ & $33.7 \mathrm{ab}$ & $3.85 \mathrm{~b}$ & $121.7 \mathrm{~b}$ \\
$\begin{array}{l}\text { Arundo } \\
\text { donax }\end{array}$ & Cicily & Leaf & $54.1 \mathrm{~b}$ & $67.6 \mathrm{ab}$ & $36.7 \mathrm{bcd}$ & $3.82 \mathrm{~b}$ & $109.0 \mathrm{bc}$ \\
$\begin{array}{l}\text { Pennisetum } \\
\text { purpureum }\end{array}$ & Merkeron & Leaf & $58.5 \mathrm{a}$ & $69.4 \mathrm{bc}$ & $36.0 \mathrm{abcd}$ & $3.04 \mathrm{a}$ & $106.7 \mathrm{bc}$ \\
$\begin{array}{l}\text { Pennisetum } \\
\text { purpureum }\end{array}$ & Merkeron & Stem & $43.5 \mathrm{~d}$ & $74.2 \mathrm{def}$ & $48.1 \mathrm{ef}$ & $6.95 \mathrm{c}$ & $105.3 \mathrm{c}$ \\
$\begin{array}{l}\text { Pennisetum } \\
\text { purpureum }\end{array}$ & N 190 & Leaf & $46.8 \mathrm{c}$ & $73.0 \mathrm{de}$ & $38.3 \mathrm{~d}$ & $3.53 \mathrm{ab}$ & $96.7 \mathrm{~cd}$ \\
$\begin{array}{l}\text { Arundo } \\
\text { donax }\end{array}$ & Fitzgerald & Leaf & $52.4 \mathrm{~b}$ & $65.5 \mathrm{a}$ & $33.7 \mathrm{a}$ & $4.14 \mathrm{~b}$ & $84.8 \mathrm{~d}$ \\
$\begin{array}{l}\text { Pennisetum } \\
\text { purpureum }\end{array}$ & N 190 & Stem & $35.9 \mathrm{e}$ & $74.1 \mathrm{def}$ & $49.1 \mathrm{f}$ & $7.90 \mathrm{~d}$ & $84.0 \mathrm{~d}$ \\
$\begin{array}{l}\text { Arundo } \\
\text { donax } \\
\begin{array}{l}\text { Arundo } \\
\text { donax }\end{array}\end{array}$ & Fitzgerald & Stem & $22.6 \mathrm{~g}$ & $75.4 \mathrm{efg}$ & $49.9 \mathrm{f}$ & $8.98 \mathrm{e}$ & $47.2 \mathrm{e}$ \\
\hline
\end{tabular}

${ }^{\mathrm{T}}$ Means with the same letter are not significantly different $(\alpha=0.05)$ 


\subsubsection{Future Outlook for Bermudagrass}

There is great potential for further improvements of bermudagrass for yield and bioconversion due to the tremendous diversity within the Cynodon taxa (Taliaferro et al. 2002). Increased knowledge of the genetic differences of cell wall components among diverse grass germplasm will help in determining specific genes of interest, and together with the development of molecular maps associated with these traits for marker-assisted selection (MAS), it will provide methods for genetic improvement of biomass species. Further histochemical and spectrophotometric evaluations will be needed on diverse germplasm to determine more specific compositional differences within specific cell types for mechanisms involved with decreased recalcitrance of grass cell walls that would facilitate increased efficiency of conversion of cellulose and hemi-cellulose portions of the dry matter to hexose and pentose sugars for fermentation (see Chapter 4). Genetic improvements of bermudagrass for conversion to ethanol through fermentation will likely coincide with forage quality improvements. This can help both the biofuel and forage industries and give growers marketing options for their hay. The current price of good-quality hay (US\$40 $-\$ 50 \mathrm{Mg}^{-1}$ ), and the relatively high requirements of nitrogen fertilizer and water may, however, limit biomass available for bioenergy to older, lower-quality feedstock.

\subsection{Napiergrass}

\subsubsection{Botanical Description}

Napiergrass (Pennisetum purpureum (L.) Schum.) is a major forage crop in the wet tropics of the world. It has the potential to produce more dry matter per unit time than most other grasses (Hanna et al. 2004). Napiergrass is in the tribe Paniceae of the Poaceae (Panicoideae) family (Bogdan 1977). It is indigenous to equatorial Africa in areas of rainfall exceeding $1,000 \mathrm{~mm}$. There is great variability with the species and naturally cross-pollination has occurred (Bogdan 1977; Skerman and Riveros 1990). Napiergrass is a bunch-type grass that produces robust, creeping rhizomatous plants that has a perennial growth habit in the tropics and subtropics and forms bamboo-like clumps that grow up to $7 \mathrm{~m}$ in height. The species grows best in regions with hot temperatures $\left(30-35^{\circ} \mathrm{C}\right)$ (Ferraris 1978); growth stops when temperatures are below $10^{\circ} \mathrm{C}$ (Bogdan 1977). Frost will kill leaves and above-ground stems, but the underground parts will resume growth at the beginning of the spring if the soil does not freeze. Napiergrass is thus adaptable to USDA hardiness zones 8 and 9 (Hanna et al. 2004). Napiergrass has wide adaptation to diverse soil conditions, but is best adapted to deep, well-drained, fertile soils. This species also has substantial drought tolerance due to its deep fibrous root system, but it responds to irrigation and it will produce large amounts of biomass when fertilized, particularly with $\mathrm{N}$ (Skerman and Riveros 1990). Napiergrass is a short-day plant that flowers when day length is $11 \mathrm{~h}$ or less, and there appears to be an interaction between day length and temperature. At Tifton, GA less than $5 \%$ of the accessions flower during an 11-h day. Plants tend to remain vegetative and leafy during long days, but as days become 
shorter the proportion of stem tissue increases and the plants change to a reproductive stage (Hanna et al. 2004).

Napiergrass is a cross-pollinated allopolyploid with $2 n=4 x=28$ chromosomes (Hanna 1981) with the genome formula $\mathrm{A}^{\prime} \mathrm{A}^{\prime} \mathrm{BB}$. The $\mathrm{A}^{\prime} \mathrm{A}^{\prime}$ genome is homologous to the AA genome of pearl millet (Pennisetum glaucum (L.) R. Br.). The A' genome chromosomes are larger than the B genome chromosomes. The B genome supplies the genes controlling perennial growth habit. Napiergrass sets few seed, partially due to self-incompatibility and the fact that a single genotype or clone may occupy a large area. Stigmas are exerted before pollen is shed, which enforces crosspollination and simplifies crossing and producing hybrids (Hanna et al. 2004).

\subsubsection{Management and Bioprocessing}

Napiergrass is generally propagated by stems and rhizomes, because most genotypes do not produce large numbers of seed. In adition, plants from seed tend to not breed true, grow slowly and are weak. Rapid multiplication and dissemination of superior germplasm is possible with vegetative propagation, but it is more labor-intensive and costly and can predispose clonal material to disease (Boonman 1993). Although some developments in mechanization for establishing napiergrass have reduced labor inputs (Sollenberger et al. 1990), there is still a need for improved mechanization for harvesting planting material and the planting process itself. Perhaps methods used in the sugarcane industry can be adapted. Woodard et al. (1985) reported that tall napiergrass is easily established from stem cuttings, especially from the lower stalk (less mature). Maximum planting depths should not exceed $10 \mathrm{~cm}$. The number of shoots that emerged from stem cuttings increased as the stems were cut into shorter pieces due to apical dominance, i.e. the buds at nodes at either end of the cutting tended to begin growth while buds at nodes between the outer nodes remained dormant.

Many studies have focused on the effects of fertilizer on yield and forage quality (Hanna et al. 2004). Under optimum experimental conditions, high fertilizer input and a year-round growing season, napiergrass is capable of producing $70-85 \mathrm{Mg} \mathrm{ha}^{-1}$ $\mathrm{yr}^{-1} \mathrm{DM}$ (Vicente-Chandler et al. 1959). Under more realistic farm practices, total DM accumulation can range from 5-10 $\mathrm{Mg} \mathrm{ha}^{-1} \mathrm{yr}^{-1}$ in unfertilized swards, and from 15-30 Mg ha ${ }^{-1} \mathrm{yr}^{-1}$ in well-fertilized pastures (Bogdan 1977; Skerman and Riveros 1990). Woodard and Prine (1990) recommended annual N-P-K fertilizer rates of 225-25-90 kg ha ${ }^{-1}$ for the released line 'Merkeron'. Highest yields are obtained under long growing seasons and warm temperatures. Napiergrass responds very well to high $\mathrm{N}$ fertilization levels. In Florida napiergrass (PI 300086) was fertilized with 330 $\mathrm{kg} \mathrm{N} \mathrm{ha}^{-1} \mathrm{yr}^{-1}$ and harvested at a $3-\mathrm{cm}$ stubble every $6,8,12$, and 24 weeks during a 24-week period (Calhoun and Prine 1985). Averaged across two years, yield increased from approximately $20-40 \mathrm{Mg} \mathrm{ha}^{-1} \mathrm{yr}^{-1}$ as the harvest interval was increased from 6 to 24 weeks. The effect of the harvesting interval varies by genotype, but in general long harvest intervals increases DM production and aids persistence (Woodard and Prine 1991; Hanna et al. 2004). Harvesting can be accomplished using conventional silage choppers with large heads if the plants are planted in spaced 
rows. Older material may require more heavy-duty equipment such as used in the sugarcane industry.

The most desirable characteristic of napiergrass is its yield potential, probably the highest among the forage grasses (Bogdan 1977; Schank and Hanna 1995). Research has shown that napiergrass consistently produces more DM than other grasses and legumes (Vicente-Chandler et al. 1974; Hoshino et al. 1979; Tergas and Urrea 1985). Cultivar 'Merkeron' yielded 27.1 Mg ha ${ }^{-1}$ versus $17.6 \mathrm{Mg} \mathrm{ha}^{-1}$ for 'Tifton 85 ' bermudagrass and $14.8 \mathrm{Mg} \mathrm{ha}^{-1}$ for 'Alamo' switchgrass when averaged over 6 years and three locations in Georgia (Table 12.2) when applying a total of $168 \mathrm{~kg} \mathrm{ha}^{-1} \mathrm{~N}$ and harvesting twice during the year. Note that yields of napiergrass were significantly lower in 2001 and to a lesser extent in 2000 . Yields of napiergrass lines tested in southern and central Florida, grown on a range of soil and cultural practices including sewage effluent and phosphate mining sites, were between 30 and $60 \mathrm{Mg}$ ha ${ }^{1} \mathrm{yr}^{-1}$ (Prine et al. 1997). Napiergrass yields in northern areas of the South have ranged from the 20 to $30 \mathrm{Mg} \mathrm{ha}^{-1} \mathrm{yr}^{-1}$ (Prine et al. 1991).

Cultivars of napiergrass are all propagated vegetatively. Alcantara et al. (1980) list a number of napiergrass cultivars. Burton (1989) selected 'Merkeron' with improved yield and disease resistance from a cross between a high-yielding clone and a dwarf leafy clone. Reynolds and Sini (1976) produced superior genotypes by intercrossing various napiergrasses. Grof (1969) selected improved genotypes from an open-pollinated progeny of a napiergrass cultivar. Hanna and Monson (1988) selected a semi-dwarf genotype from the $\mathrm{F}_{2}$ progeny of 'Merkeron', which was released as 'Mott' (Sollenberger et al. 1988). A more recent publication by Xavier et al. (1995) listed additional cultivars available in Brazil.

\subsubsection{Genetics and Breeding}

Napiergrass is known to possess genetic improvement potential through the availability of diverse genetic clones that can be recombined through traditional crossbreeding. This could lead to much higher sustainable yields than already attained, reducing the production area needed for biomass feedstocks and reducing transport costs. Extensive breeding and yield evaluations were performed in Florida during the 1980 's. Germplasm varies for cold tolerance (survived $-18^{\circ} \mathrm{C}$ at Tifton, GA) which makes it possible to extend the use of this plant into the subtropics. Accessions vary in their ability to retain leaves after frost. The 100 -accession napiergrass nursery at Tifton, GA was rated for leaf retention in mid-February after killing frosts in midDecember. On a rating scale of 1 (complete leaf retention) to 5 (no leaf retention), over $30 \%$ of the clones have a rating of less than 3 . Most of these clones are dwarf or semi-dwarf, but some are erect, robust types (Hanna et al. 2004). Interspecific crosses with pearl millet further increases genetic variability yield, pest resistance, and other desirable traits, such as methane yield resulting from anaerobic fermentation reactions (Schank et al. 1993; Hanna et al. 1984). Leaf/stem ratios varied between 0.12 and 0.87 in the nursery. The range of NDF within the Tifton nursery ranged from 653 to $844 \mathrm{~g} \mathrm{~kg}^{-1}$ (unpublished data).

Napiergrass exhibits progyny (i.e. the stigma is receptive before the anthers release pollen); stigmas are exerted over a 3-4 day period, beginning at the top of the 
inflorescence. The anthers are exerted later for a similar length of time. This allows crossing to take place by placing glassine bags possessing pollen from the male parent over the receiving female inflorescence (Hanna et al. 2004).

Due to the sufficient fertility to produce viable hybrid seed, napiergrass is conducive to genetic improvement through breeding and has been crossed with annual pearl millet for improved quality. The interspecific hybrid is a triploid (AA ' B genomes) with $2 n=3 x=21$ chromosomes (seven chromosomes from pearl millet and 14 chromosomes from napiergrass). Triploid hybrids resulting from the interspecific cross are usually highly variable because of the heterozygosity of napiergrass, even if the pearl millet parent is an inbred (Hanna et al. 2004). Fertility can be induced in the sterile triploid hybrid by doubling the chromosome number to produce a male and female fertile hexaploid with $2 n=6 x=42$ chromosomes. The hexaploid interspecific hybrid has potential as a seed- as well as vegetatively-propagated biomass feedstock if seedling vigor and persistence can be improved. Schank and Diz (1991) reported on stable seed-propagated interspecific hybrids that combined yield and quality of the hybrid with the convenience of seed production. The hexaploid can be backcrossed to pearl millet to produce vigorous $2 n=4 x=28$ plants (AAA'B genomes). These hybrids can be quite leafy and high in quality, similar to pearl millet, due to the extra A genome. They are completely male- and female-sterile, perennial like the triploid, and must therefore be vegetatively propagated. The largest collection of napiergrass germplasm is present at the nursery in Tifton, GA where over 100 plant introductions from around the world and breeding line material from intra- and interspecific crosses are maintained (Hanna et al. 2004).

Napiergrass was also successfully crossed with Pennisetum squamulatum Fresen., an apomictic species, to produce partially seed-fertile apomictic interspecific hybrids at Tifton, GA (Hanna et al. 2004). It should be possible through continued backcrossing to transfer the gene(s) controlling apomixis to napiergrass. Apomixis could be used to produce true-breeding, seed-propagated cultivars in napiergrass and the pearl millet $\times$ napiergrass interspecific hexaploid hybrids regardless of the heterozygosity of the cultivars.

The potential exists to alter cell wall components conducive to the breakdown and conversion to ethanol. Preliminary analysis of the napiergrass cultivar 'Merkeron' revealed a significant release of fermentable sugars after ferulic acid esterase pretreatment followed by cellulase (Table 12.5), although it still needs to be investigated whether compounds that inhibit conversion to ethanol were released (Anderson et al. 2005). In a separate study leaves were separated from stems in two napiergrass genotypes and analyzed for conversion to ethanol using a standard SSF method (Table 12.4). Variability existed between the two genotypes and to a lesser extent between the leaf and stem portions. To some extent the variation was correlated to NDF content.

Digestibility and fiber analyses have been performed on the 100-accession napiergrass nursery located at Tifton, GA that includes interspecific hybrids with $P$. glaucum and $P$. squamulatum. Mature stalks were sampled over two years; leaf and stem were separated and analyzed separately for in vitro dry matter digestibility (IVDMD), NDF, ADF and acid detergent lignin (ADL). Values for IVDMD were generally higher for leaves (Table 12.6). NDF, ADF and ADL were higher for stems 
(Table 12.6). Genetic diversity of napiergrass has also been performed using molecular techniques. Among 240 scorable AFLP $^{\circledR}$ fragments amplified from genomic DNA of plants in the Tifton napiergrass nursery, approximately $43 \%$ were polymorphic for the initial six selectable primer pairs (unpublished results). Schank et al. (1989) reported significant genomic variation among a limited number of napiergrass clones using restriction fragment length polymorphisms (RFLPs; see Chapter 6). Smith et al. (1989) prepared and used a partial genomic library to differentiate 21 napiergrass clones via RFLP analyses and found an average polymorphism rate of $31.7 \%$ across all pair-wise combinations.

Table 12.5. Dry weight loss and compounds released from grasses treated with ferulic acid esterase and cellulase. Data kindly supplied by D.K. Akin (USDA-ARS)

\begin{tabular}{|c|c|c|c|c|c|c|}
\hline \multirow[b]{3}{*}{ Plant } & \multirow[b]{3}{*}{$\begin{array}{l}\text { Age } \\
{[\mathrm{wks}]}\end{array}$} & \multirow[b]{3}{*}{$\begin{array}{l}\text { Dry Weight } \\
\text { Loss[\%] }\end{array}$} & \multicolumn{4}{|c|}{ Compounds released in supernatant } \\
\hline & & & \multicolumn{2}{|c|}{ Phenolic acids } & \multicolumn{2}{|c|}{ Sugars } \\
\hline & & & $\begin{array}{l}\mathrm{pCA}^{1} \\
{[\mathrm{mg} / \mathrm{g}]}\end{array}$ & $\begin{array}{l}\mathrm{FA}^{1} \\
{[\mathrm{mg} / \mathrm{g}]}\end{array}$ & $\begin{array}{l}\text { pentose }^{1} \\
{[\mathrm{mg} / \mathrm{g}]}\end{array}$ & $\begin{array}{l}\text { hexose } \\
{[\mathrm{mg} / \mathrm{g}]^{1}}\end{array}$ \\
\hline \multirow[t]{2}{*}{ Napiergrass } & 4 & $64.4 a$ & $0.65 d$ & $0.14 \mathrm{f}$ & $24.8 \mathrm{c}$ & $130.2 \mathrm{bc}$ \\
\hline & 8 & $46.4 d$ & $0.65 \mathrm{~d}$ & $0.37 \mathrm{ef}$ & $18.8 \mathrm{~d}$ & $96.7 \mathrm{e}$ \\
\hline \multirow{2}{*}{ Bermudagrass $^{2}$} & 4 & $49.7 \mathrm{c}$ & $1.05 \mathrm{a}$ & $1.28 \mathrm{a}$ & $17.8 \mathrm{de}$ & $88.0 \mathrm{e}$ \\
\hline & 8 & $42.2 \mathrm{e}$ & $0.76 \mathrm{c}$ & $0.75 \mathrm{~cd}$ & 16.0defg & $117.3 \mathrm{~cd}$ \\
\hline Corn leaf blade & & $61.8 \mathrm{~b}$ & $0.31 \mathrm{~g}$ & $0.58 \mathrm{de}$ & $44.6 \mathrm{ab}$ & $135.5 b$ \\
\hline Corn leaf sheath & & $62.7 \mathrm{~b}$ & $0.52 \mathrm{f}$ & $0.82 b c$ & $49.3 \mathrm{a}$ & $198.2 \mathrm{a}$ \\
\hline Corn leaf rind & & $20.5 \mathrm{j}$ & $0.75 \mathrm{c}$ & $0.40 \mathrm{ef}$ & $17.3 \mathrm{def}$ & $36.8 \mathrm{f}$ \\
\hline Corn leaf pith & & $28.8 \mathrm{i}$ & $0.95 b$ & $0.87 b c$ & $41.6 \mathrm{~b}$ & $87.0 \mathrm{e}$ \\
\hline
\end{tabular}

${ }^{\mathrm{T}}$ Entries with the same letter are not significantly different $(\alpha=0.05)$

Table 12.6. Average values (in \%) based on two replicates of in vitro dry matter digestibility (IVDMD), neutral detergent fiber (NDF), acid detergent fiber (ADF), acid detergent lignin (ADL) and leaf dry matter weight as a percentage of the total dry matter weight (Leaf DM) of three parental lines and range within the napiergrass nursery harvested November 2005 at Tifton, GA

\begin{tabular}{lccccc}
\hline Plant genotype & IVDMD [\%] & NDF [\%] & ADF [\%] & ADL [\%] & Leaf DM [\%] \\
\hline Merkeron & & & & & \\
$\quad$ Leaf & 53.4 & 70.2 & 36.5 & 3.15 & 22.5 \\
$\quad$ Stem & 29.8 & 80.3 & 54.5 & 10.65 & \\
N 51 & & & & & \\
$\quad$ Leaf & 55.8 & 66.3 & 34.6 & 2.74 & 24.8 \\
$\quad$ Stem & 28.3 & 79.5 & 56.8 & 10.29 & \\
SC 1125-3 & & & & & \\
$\quad$ Leaf & 47.8 & 78.0 & 45.3 & 3.95 & 21.9 \\
$\quad$ Stem & 33.6 & 78.7 & 54.5 & 12.66 & \\
\hline Nursery Range & & & & & \\
$\quad$ Leaf & $34.8-60.2$ & $62.5-78.0$ & $33.7-45.7$ & $2.33-4.98$ & $10.5-63.9$ \\
$\quad$ Stem & $21.9-51.3$ & $66.7-83.2$ & $40.5-59.7$ & $5.05-12.66$ & \\
\hline
\end{tabular}




\subsubsection{Future Outlook for Napiergrass}

Napiergrass has great potential as a biofuel feedstock primarily because of its high yield potential. Though most of the dry weight of the plant is stem, genetic variability appears to be present to alter either leaf/stem ratios or stem cell wall components or both to make it more amenable to degradation. If thermo-chemical processes are used, then yield and ash content become the primary genetic traits to alter. More research is required if the biomass needs to be dried prior to trabsport and bioprocessing. Improving leaf retention to enhance crop drying in the field prior to harvest may be essential. Developing seeded varieties with or without apomixis should be possible through hybridization with related annual and perennial species. Cold tolerance should be improved to enable growth in northern hardiness zone 8 and into zone 7 . The fact that flowering is day-length sensitive may be an advantage. Crossing and seed production could be accomplished in southern areas of Florida or Texas (hardiness zone 9), while the inability to outcross and set seed in climate zones 7 and 8 would reduce invasiveness of the crop and direct all nutrient sinks to vegetative production. Tremendous genetic variability exists in germplasm within the United States to accomplish many of these goals. External sources of germplasm may also be available.

\subsection{Eastern Gamagrass}

\subsubsection{Botanical Description}

Eastern gamagrass (Tripsicum dactyloides L.) shares the same subtribe as maize (Zea mays; Chapter 7). It is a native perennial warm-season bunchgrass of the eastern United States extending from central Texas to southeastern Nebraska and central Iowa and east to the Atlantic Ocean. Eastern gamagrass ranges in height from 1 to 3 $\mathrm{m}$ (USDA-NRCS 2006). It is highly palatable for grazing, which may be the primary reason it has been overgrazed, resulting in reduced native stands (Kindiger and Dewald 1997). Leaves are 30-95 $\mathrm{mm}$ long and 1-6 mm wide. Plants will reproduce vegetatively from proaxes, which are similar to knotty rhizomes. It forms seed from racemes which are 30-50 mm long. Gamagrass does best in well-drained soils with a $\mathrm{pH}$ range of 5.1-7.5 (USDA-NRCS 2006). It is monoecious with both male and female flowers on the raceme. The top three-quarter of the raceme is made up of male flowers and the bottom one-quarter of female flowers (Springer and Dewald 2004). Seed set is low and generally has a low germination rate. One exception is a mutant form which is gynomonoecious (Dewald and Dayton 1985). This mutant was identified in 1981 at the USDA-NRCS Plant Materials Center (Springer and Dewald 2004) and shown to be the result of a recessive mutation (Dewald et al. 1987). This mutant has been used to produce hybrids with a 20-25-fold increase in seed set (Springer and Dewald 2004). Eastern gamagrass is predominatly diploid $(2 n=2 x=$ 36) and tetraploid, but only the diploids are sexual and cross-pollinated, whereas the tetraploids are apomictic (Burson et al. 1990). 


\subsubsection{Management and Bioprocessing}

The primary reason limiting the use of eastern gamagrass as a forage or bioenergy feedstock is the difficulty of obtaining good establishment (Springer et al. 2004). Most often up to $15 \mathrm{~kg} \mathrm{ha}^{-1}$ of fungicide-treated seed are planted in the early spring using similar methods and sowing equipment as used for maize and established methods of weed control are used after planting (USDA-NRCS 2006). It is necessary to break seed dormancy by either moist scarification (i.e. placing seeds in warm, moist containers), removing the cupule, or applying hydrogen peroxide (USDANRCS 2006). However, winter planting of non-scarified seed has been recommended (USDA-NRCS 2006). Factors limiting yield are primarily water availability (800 mm optimum) and nitrogen fertilization $\left(224 \mathrm{~kg} \mathrm{~N} \mathrm{ha}^{-1}\right)$. Yields are maximized when harvesting at 6 -week intervals, two or three times per year (Dewald et al. 2004). Yields have ranged from 6 to $16 \mathrm{Mg} \mathrm{ha}^{-1}$ (USDA-NRCS 2006). The grass is cut, dried and baled similar to most forage species when used as hay. Most research, however, has focused on eastern gamagrass as a grazing forage.

The energy-profit ratio of using eastern gamagrass in the Conservation Reserve Program for biocrude was determined to be similar to using big bluestem or indiangrass (Nelson et al. 1994). One attractive aspect of eastern gamagrass is the low nitrogen and phosphate uptake levels compared to other warm-season grasses (Esquivel et al. 2000), which would be an advantage in direct combustion or pyrolysis. When left in the field to leach nutrients, however, eastern gamagrass lodges and looses biomass (USDA-NRCS 2006). Breeding efforts should focus on improved yields, lower inputs and reduced lodging.

\subsubsection{Genetics and Breeding}

The female florets mature much faster than the male florets on the same inflorescence (Dewald and Kindiger 2000). Methods used for pollinations of eastern gamagrass are described by Dewald and Kindiger (1994). Emasculations are often performed to reduce pollen contamination. This is achieved by removing the terminal male section of the inflorescence and then covering the lower female portion with pollination bags (Kindiger and Dewald 1997). The work of Kindiger and Dewald (1997) helped identify methods of transferring genes between the sexual diploids and apomicitic tetraploids. They found that triploids and hexaploids were useful cytotypes to introgress and transfer desirable alleles across species and reproductive barriers, and that these crossing schemes could help discover and utilize the diversity within the genus.

A great deal of genetic variability exists within the Tripsicum species as it has only been recently domesticated. Cultivar and germplasm releases began in 1988 with the sexual diploid 'Pete' and have been followed by a number of apomictic tetraploids (USDA-NRCS 2006). The latest cultivar,'Verl', was released in 2005 by the USDA-ARS with the Oklahoma Agricultural Experiment Station and USDANRCS (Springer et al. 2006). 'Verl' is a fertile triploid $(2 n=3 x=54)$ that was produced by crossing a gynomonoecious diploid $(2 n=2 x=36)$ with a tetraploid $(2 n=$ 
$4 x=72$ ). It has excellent seed production, but is susceptible to maize billbug and southern cornstalk borer (USDA-NRCS 2006).

Blakey et al. (2007) provided an excellent review of Tripsicum genetics and provide a comparison with maize. The major emphasis in early studies on eastern gamagrass was to transfer the gene(s) conferring apomixis into maize and to determine the genetics of the trait. Currently, gynomonecious sex form 1 ( $g s f l$ ) is the only phenotypic trait placed on the Tripsicum genetic map and Goldman (2006) has developed a PCR-based marker for the presence of this trait in Tripsicum breeding stocks. A Tripsicum genetic map has been constructed (Lawrence et al. 2005), which will help in future work on targeting traits of interest for MAS in eastern gamagrass.

The USDA-ARS Southern Plains Range Research Station (SPRRS), Woodward, OK $\left(36^{\circ} 25^{\prime} \mathrm{N}, 99^{\circ} 24^{\prime} \mathrm{W}\right.$, elevation $\left.586 \mathrm{~m}\right)$ has maintained a large vegetative collection of eastern gamagrass since 1976 that holds presently about 400 accessions. This collection consists of wild germplasm collected throughout the eastern half of the U.S. as well as experimental lines developed at the SPRRS. The accessions include diploid types that undergo sexual reproduction, and triploid and tetraploid types that reproduce by apomixis. It also contains plants that are homozygous for the recessive gynomonoecious gsfl allele (Springer - personal communication). Tropical accessions are present within the USDA-NGRP.

An in vitro ruminal (IVR) digestion assay for estimation of ethanol production was first tested with switchgrass, big bluestem and eastern gamagrass (Weimer et al. 2005). This method greatly reduces time and expense in evaluating feedstocks for ability to ferment to ethanol. Eastern gamagrass gave the best fit in a linear regression between gas production from IVR and ethanol production $\left(\mathrm{R}^{2}=0.824\right)$. This method along with the traditional IVDMD and in vitro organic matter digestibility (IVOMD) methods were used in a second study that evaluated eastern gamagrass, big bluestem and what is referred to a sand bluestem at multiple locations over three years (Weimer and Springer 2007). They reported that big bluestem had higher fermentability than either eastern gamagrass or sand bluestem, but that yields were higher for eastern gamagrass over locations $\left(6.0-7.9 \mathrm{Mg} \mathrm{h}^{-1}\right)$ than either big bluestem (3.9-4.5 Mg ha ${ }^{-1}$ ) or sand bluestem (5.9-6.4 $\mathrm{Mg} \mathrm{ha}^{-1}$ ). There were, however, significant environmental effects on fermentability, as well as significant varietal differences. Both 'Pete' and 'Verl' had superior ruminal fermentation abilities (Weimer and Springer 2007). Another significant development from the study was the apparent success of calibrating near infrared spectroscopy (NIR; see Chapter 5) with both in vitro fermentative gas production and in vitro digestibility from standard IVDMD and IVOMD. The much faster and more efficient NIR technique would greatly enhance breeding and selection efforts for improving these grasses for conversion to ethanol.

\subsubsection{Future Outlook for Eastern Gamagrass}

Eastern gamagrass is a native grass that has been genetically improved to a limited extent for use as forage. Recent advances in breeding mechanisms, the great amount of genetic variability and cross compatibility between sexual and apomictic types suggest that there is great potential of improving the species as a bioenergy feed- 
stock. If feedstock material is be harvested from CRP land, the use of native species may be an advantage to producers and land owners. Though the use of molecular genetics for developing markers for MAS is currently limited to the gsfl gene, it should be possible to use information from the Tripsicum map and information from the closely related maize genome to develop molecular tools for the improvement of the Tripsicum species.

\subsection{Summary}

In the United States a tremendous area is currently planted with perennial grasses and legumes used for forage. Planting, maintenance, harvest techniques and equipment are well established for both native and introduced species. Genetic improvements for yield and cell wall degradation have been achieved in many species, with potential for improvement in all species that are suitable as biomass feedstocks. In many cases yield is comparable to switchgrass or other proposed feedstocks, but sufficient water and soil fertility is often required for superior production. Exploitation of perennial species is being driven by these species' ability to seasonally scavenge nutrients from their above-ground biomass and store them in their crown during the winter months to be remobilized in the spring for rapid growth. Producing these grasses for quality forage requires timely harvest to maintain high digestibility, low fiber, high crude protein, and high mineral content. Delaying harvest of perennial grasses results in above ground biomass that is higher in fiber and lower in minerals and proteins than material harvested during the growing season (Perry and Baltensperger 1979; Griffin and Jung 1983; Forwood and Magai 1992). While switchgrass has myopically dominated research on biomass conversion for ethanol production, other species merit research, because basing such massive production on a single species bears inherent risks. The warm-season grass species discussed in this chapter merit attention, especially with regard to particular agronomic characteristics.

Probably the greatest shortcoming as a potential feedstock is the competition for use. The great majority of production area is used for grazing, with the remainder used for hay production (especially alfalfa). The profit obtained by growers in the form of cattle gains or hay for forage currently drives the market. Possibly the best scenario lies with alfalfa in which a separation of leaves and stems could provide higher value to the crop than its current value. Feedstock for biofuel will provide a secondary market for the perennial grasses, especially when forage land is not managed for the required quality needed as forage, or when climate prevents harvesting at the appropriate time.

Napiergrass, however, is the one grass reviewed in this chapter that has potential as a dedicated bioenergy feedstock. It is currently not an important forage in the U.S., but high yields have been obtained in many areas into the USDA hardiness zone 7. Sufficient intra- and inter-specific genetic variability appears to be present to further improve yields. Leaf retention and plant characteristics will need to be altered to adapt to methods of harvest that could reduce moisture and mineral content once the crop has senesced. If processing requires cell wall breakdown to fermentable 
sugars, genes from brown midrib pearl millet should be transferable to napiergrass. Cold tolerance and low inputs for production are two further traits requiring improvements.

\section{Acknowledgments}

We want to thank Dr. Steve Larson (USDA ARS Forage and Range Research Lab, Utah State University, Logan, UT) for correspondence and unpublished information, Dr. C. Corley Holbrook (USDA ARS, Crop Genetics and Breeding Research Unit, Tifton, GA) and Dr. Wayne W. Hanna (Universtiy of Georgia, Tifton, GA) for internal reviews.

\section{References}

Adler, P.R., Sanderson, M.A., Boateng, A.A., Weimer, P.J., and Jung, H.G. (2006) Biomass yield and biofuel quality of switchgrass harvested in fall or spring. Agron. J. 98,15181525 .

Akin, D.E., Ames-Gottfred, N., Hartley, R.D., Fulcher, R.G., and Rigsby, L.L. (1990) Microspectrophotometry of phenolic compounds in bermudagrass cell walls in relation to rumen microbial digestion. Crop Sci. 30,396-401.

Alcantara, P.B., Alcantara, V.D.B.G., and Almeida, J.E.D. (1980) Studies on 25 prospective varieties of elephantgrass (Pennisetum purpureum Schum.). Bol. Ind. Anim. 37,279-302.

Alderson, J., and Sharpe, W.C. (1994) Grass varieties in United States. Agriculture Handbook No. 170. USDA, SCS, Washington, DC.

Anderson, D.E. (1961) Taxonomy and distribution of the genus Phalaris. Iowa State J. Sci. $36,1-96$.

Anderson, W.F. (2005) Development of a forage bermudagrass (Cynodon sp.) core collection. Grassland Sci. 51,305-308.

Anderson, W.F. (2006) Digestibility and fiber of a forage bermudagrass core collection. ASACSSA-SSSA International Meetings Nov. 12-16, http://a-c-s.confex.com/crops/2006am/ techprogram/P21742.HTM.

Anderson, W.F., Dien, B.S., Brandon, S.K., and Peterson, J.D. (2008) Assessment of bermudagrass and bunch grasses as feedstock for conversion to ethanol. Appl. Biochem. Biotechnol. 14,13-12.

Anderson, W.F., Peterson, J.D., Akin, D.E., and Morrison, W.H., III. (2005) Enzyme pretreatment of grass lignocellulose for potential high-value co-products and an improved fermentable substrate. Appl. Biochem. Biotechnol. 121-124,303-310.

Arinze, E.A., Schoenau, G.J., Sokhansanj, S., and Adapa, P. (2003) Aerodynamic seperation and fractional drying of alfalfa leaves and stems - A review and new concept. Drying Technol. 21,1669-1698.

Baldwin, B.S., and Cossar, R.D. (2005) Yield of four warm-season grasses and post frost losses due to weathering. (Proc.) 4th Eastern Native Grass Symposium. The University of Kentucky Department of Forestry, 3-6 October 2004, Lexington, KY. pp. 31-36.

Barkworth, M.E., and Atkins, R.J. (1984) Leymus hochst. (Gramineae: Triticeae) in North America: Taxonomy and distribution. Amer. J. Bot. 71,609-625.

Barnes, D.K., and Stephenson, M.G. (1971) Relative efficiences of four self-pollination techniques in alfalfa. Crop. Sci. 11,131-132. 
Barnes, D.K., Bingham, E.T., Murphy, R.P., Hunt, O.J., Beard, D.F., Skrdla, W.H., and Teuber, L.R. (1977) Alfalfa germpalsm in the United States: Genetic vulnerability, use, improvement, and maintenance. U.S. Department of Agriculture, Tech. Bull. 1571, Washington, DC. pp. 1-21.

Benes, S.E., Basinal, L.M., Finch, C., and Gratten, S.R. (2005) Crop selection for IFDM systems. In Technical Advisor's Manual, Managing Agricultural irrigation drainage water. A guide for developing integrated on form drainage management systems J.E. Ayars, T. Jacobsen and L. Basiral (eds.). Westside Resources Conservation District Chapter 5. pp. 1-7.

Bennett, O.L. and Doss, B.D. (1960) Effect of soil moisture level on root distribution of coolseason forage species. Agron. J. 52,204-207.

Blakey, C.A., Costich, D., Sokolov, V., and Islam-Faridi, M.N. (2007) Tripsicum genetics: From observations along a river to molecular genomics. Maydica 52,81-99.

Boateng, A.A., Jung, H.G., and Adler, P.R. (2006) Pyrolysis of energy crops including alfalfa stems, reed canarygrass, and eastern gamagrass. Fuel 85,2450-2457.

Boateng, A.A., Anderson, W.F., and Phillips, J.G. (2007) Bermudagrass for biofuels: Effect of two genotypes on pyrolysis product yield. Energ. Fuel. 21,1183-1187.

Bogdan, A.V. (1977) Tropical pasture and fodder crops. Tropical agriculture series. Longman Group Ltd., London, UK.

Boonman, J.G. (1993) East Africa's grasses and fodders: Their ecology and husbandry. Kluwer Academic Publishers. London, England.

Bouton, J.H. (2002) Bioenergy crop breeding and production research in the southeast - Final report for 1996-2001, Oak Ridge Nat. Lab. Report ORNL/SUB-02-19XSV810/01.

Bransby, D. (2006) Generating ethanol from alternative crop biomass. ASA-CSSA-SSSA International Meetings Nov. 12-16, http:/crops.confex.com/crops/2006am/techprogram/ 24088.HTM.

Brummer, E.C., Bouton, J.H., and Kochert, G. (1993) Development of an RFLP map in diploid alfalfa. Theor. Appl. Genet. 86,329-332.

Burson, B.L., Voigt, P.W., Sherman, R.A., and Dewald, C.L. (1990) Apomixis and sexuality in eastern gamagrass. Crop Sci. 30,86-89.

Burton, G.W. (1948) Coastal bermudagrass. Cir. 10. revised Ga Agric. Exp. Stn., Athens. 21 p.

Burton, G.W. (1951) Intra- and inter-specific hybrids in bermudagrass. J. Hered. 42,153-156.

Burton, G.W. (1956) Utilization of heterosis in pasture plant breeding. In G.J. Neale (ed.) Proc. Int. Grassl. Congr., 7th, Palmerston, North, NZ. 6-12 Nov. 1956. Wright and Carman, Wellington, NZ. pp. 3-12.

Burton, G.W. (1972) Registration of 'Coastcross-1' bermudagrass. Crop Sci. 12,125.

Burton, G.W. (1989) Registration of 'Merkeron' napiergrass. Crop Sci. 29,1327.

Burton, G.W., DeVane, E.H. and Carter, R.L. (1954) Root penetration, distribution and activity in southern grasses measured by yields, drought symptoms and $\mathrm{P}^{32}$ uptake. Agron. J. 46,229-233.

Burton, G.W., Gates, R.N. and Hill, G.M. (1993) Registration of 'Tifton 85' bermudagrass. Crop Sci. 33,644-645.

Burton, G.W., and Hanna, W.W. (1995) Bermudagrass. In R.F. Barnes et al. (eds.) Forages An introduction to grassland agriculture. Vol. 1. Iowa State Univ. Press, Ames. pp. 421429.

Burton, G.W., and Hart, R.H. (1967) Use of self-incompatibility to produce commercial seepropagated $\mathrm{F}_{1}$ bermudagrass hybrids. Crop Sci. 7,524-527.

Burton, G.W., Jackson, J.E. and Hart, R.H. (1963) Effects of cutting frequency and nitrogen on yield, in vitro digestibility, and protein, fiber, and carotene content of Coastal bermudagrass. Agron. J. 55,500-502.

Burton, G.W., and Monson, W.G. (1972) Inheritance of dry matter digestibility in bermudagrass, Cynodon dactylon (L.) Pers. Crop 12,375-378.

Burton, G.W., and Monson, W.G. (1984) Registration of 'Tifton 68' bermudagrass. Crop Sci. 24,1211 . 
Burton, G.W., and Monson, W.G. (1988) Registration of 'Tifton 78' bermudagrass. Crop Sci. 28,187-188.

Buxton, D.R., and Anderson, I.C. (1992) Selection of herbaceous energy crops for production in double cropping systems. In Proc. Ann. Automotive Tech. Dev. Contractor's Meeting. 28-31 Oct. 1991, Dearborn, MI. Soc. Automotive Eng., Warrandale, PA. pp. 709-712.

Buxton, D.R., and Wedin, W.F. (1970) Establishment of perennial forages. I. Subsequent yields. Agron. J. 62,93-97.

Calhoun, D.S., and Prine, G.M. (1985) Response of elephantgrass to harvest interval and method of fertilization in the cooler subtropics. Soil Sci. Soc. Fla. Proc. 44,112-115.

Carlson, I.T., Oram, R.N., and Surprenant, J. (1996) Reed canarygrass and other phalaris species. In L.E. Moser et al. (eds.) Cool-Season Forage Grasses. ASA-CSSA-SSSA, Madison, WI. pp. 569-604.

Casler, M.D. and Hovin, A.W. (1980) Genetics of vegetative stand establishment characters in reed canarygrass clones. Crop Sci. 20,511-515.

Casler, M.D., and Hovin, A.W. (1985) Forage yield prediction from morphological traits in reed canarygrass. Crop Sci. 25,783-787.

Casler, M.D., and Undersander, D.J. (2006) Selection for establishment capacity in reed canarygrass. Crop Sci. 46,1277-1285.

Cassida, K.A., Muir, J.P., Hussey, M.A., Read, J.C., Venuto, B.C., and Ocumpaugh, W.R. (2005) Biomass yield and stand characteristics of switchgrass in south central U.S. environments. Crop Sci. 45,673-681.

Decker, A.M., Jung, G.A., Washko, J.B., Wolf, D.D., and Wright, M.J. (1967) Management and productivity of perennial grasses in the northeast. I. Reed canarygrass. West Virginia Agric. Exp. Stn. Bull. 550T.

Delucia, E.H., Heckthorn, S.A., and Day, T.A. (1992) Effects of soil temperature on growth, biomass allocation and resource acquisition of Andropogon gerardii Vitman. New Phytol. $120,543-549$.

Dewald, C.L., Burson., B.L., de Wet, J.M.J., and Harlan, J.R. (1987) Morphology, inheritence, and evolutionary significance of sex reversal in Tripsacum dactyloides (Poaceae). Am. J. Bot. 74,1055-1059

Dewald, C.L., and Dayton, R.S. (1985) A prolific sex form variant of eastern gamagrass. Phytologia 57,156.

Dewald, C.L., and Kindiger, B. (1994) Genetic transfer of gynomonocy from diploid to triploid eastern gamagrass. Crop Sci. 34,1259-1262.

Dewald, C.L., and Kindiger, B. (2000) Genetic advances in eastern gamagrass seed production. In K. Moore and B. Anderson (eds.) Native Warm-Season Grasses: Research, Trends, and Issues. CSSA Special Publ. 30. CSSA. Madison, WI. pp. 123-132.

Dewey, D.R. (1984) The genomic system of classification as a guide to intergeneric hybridization with the perennial Triticeae. In J.P. Gustafson (ed.) Gene Manipulation in Plant Improvement. Proc. 16th Stadler Genetics Symp. Columbia, MO. 19-21 March. Plenum, New York. pp. 209-279.

Dien, B.S., Jung, H.G., Vogel, K.P., Casler, M.D., Lamb, J.F.S., Iten, L. Mitchell, R.B., and Sarath, G. (2006) Chemical composition and response to dilute-acid pretreatment and enzymatic saccharification of alfalfa, reed canarygrass, and switchgrass. Biomass Bioenerg. 30,880-891.

Echt, C.S., Kidwell, K.K., Knapp, S.J., Osborn, T.C., and McCoy, T.J. (1994) Linkage mapping in diploid alfalfa (Medicago sativa). Genome 37,61-71.

Eichhorn, Jr., M.M., Oliver, W.M., Hallmark, W.B., Young, W.A., Davis, A.V., and Nelson, B.D. (1986) Registration of 'Grazer' bermudagrass. Crop Sci. 26,835.

Esquivel, R.G., Williams, R.D., MacKown, C.T., and Lemunyon, J.L. (2000) Response of perennial forages and a forb as filter strips for nitrogen and phosphorus removal. In Eastern Gamagrass Technology Update. USDA, NRCS Plant Materials Program. pp. 27-28, http://www.plant-materials.nrcs.usda.gov/pubs/mspmcpul204.pdf. 
Ferraris, R. (1978) The effect of photoperiod and temperature on the first crop and ratoon growth of Pennisetum purpureum Schum. Aust. J. Agric. Res. 29,941-950.

Ferrer, A., Byers, F.M., Sulbaran-de-Ferrer, B., Dale, B.E., and Aiello, C. (2002) Optimizing ammonia processing conditions to enhance susceptibility of legumes to fiber hydrolysisalfalfa. Appl. Biochem. Biotech. 98,123-143.

Forbes, I., and Burton, G.W. (1963) Chromosome number and meiosis in some Cynodon species and hybrids. Crop Sci. 3,75-79.

Forwood, J.R., and Magai, M.M. (1992) Clipping frequency and intensity effects on big bluestem yield, quality, and persistence. J. Range Manage. 45,554-559.

Goldman, J.J. (2006) High-throughput DNA extraction and allele specific PCR primers enables efficient screening of mutant $(g s f)$ and wild type $(G S F)$ alleles in eastern gamagrass. Crop Sci. 46,362-364.

Gould, F.W. (1968) Grass systematics. McGraw-Hill Book Co. New York, NY.

Gould, F.W., and Shaw, R.B. (1983) Grass systematics. 2nd ed. Texas A\&M Univ. Press, College Station, TX.

Green, E.K., and Galatowitsch, S.M. (2001) Differences in wetland plant community establishment with additions of nitrate- $\mathrm{N}$ and invasive species (Phalaris arundinacea and Typha $\times$ glauca). Can. J. Bot. 79,170-178.

Griffin, J.L., and Jung, G.A. (1983) Leaf and stem forage quality of big bluestem and switchgrass. Agron. J. 75,723-726.

Grof, B. (1969) Elephant grass for warmer and wetter lands. Queensland Agric. J. 94,227-234.

Hallam A., Anderson, I.C., and Buxton, D.R. (2001) Comparative economic analysis of perennial, annual and intercrops for biomass production. Biomass Bioenerg. 21(6),407-424.

Hanna, W.W. (1981) Method of reproduction in napiergrass and in the $3 \mathrm{x}$ and $6 \mathrm{x}$ alloploid hybrids with pearl millet. Crop Sci. 21,123-126.

Hanna, W.W., Chaparro, C.J., Mathews, B.W., Burns, J.C., Sollenberger, L.E. (2004) Perennial Pennisetums. In L.E. Moser, B.L. Burson, L.E. Sollenberger (eds.) Warm-Season $\left(\mathrm{C}_{4}\right)$ Grasses. American Society of Agronomy Monograph Series no. 45, Madison pp 503-535.

Hanna, W.W., Gaines, T.P., Gonzalez, B., and Monson, W.G. (1984) Effect of ploidy on yield and quality of pearl millet X napiergrass hybrids. Agronomy J. 76,969-971.

Hanna, W.W., and Monson, W.G. (1988) Registration of dwarf Tift-N75 napiergrass germplasm. Crop Sci. 28,870-871.

Harlan, J.R., and de Wet, J.M.J. (1969) Sources of variation in Cynodon dactylon (L.) Pers. Crop Sci. 9,774-778.

Harlan, J.R., de Wet, J.M.J., Huffine, W.W., and Deakin, J.R. (1970a) A guide to the species of Cynodon (Gramineae). Bull. B-673. Okla. Agric. Exp. Stn., Stillwater 37 p.

Harlan, J.R., de Wet, J.M.J., Rawal, K.M.., Felder, M.R., and Richardson, W.L. (1970b) Cytogentic studies in Cynodon L.C. Rich (Gramineae). Crop Sci. 10,288-291.

Hatfield, R.D., Mandebvu, P., and West, J. (1997) A comparison of Tifton 85 and Coastal bermudagrass cell walls. Annual Research Summary, U.S. Dairy Forage Research Center, Madison, WI.

Hoshino, M., Ono, S., and Sirikiratayanond, N. (1979) Dry matter production of tropical grasses and legumes and its seasonal change in Thailand. J. Japan. Soc. Grassl. Sci. 24,310-317.

Hsu, F.H., Nelson, C.J., and Matches, A.G. (1985) Temperature effects on germination of perennial warm season forage grasses. Crop. Sci. 25,215-220.

Jefferson, P.G., McCaughey, W.P., May, K., Woosaree, J., and MacFarlane, L. (2004) Potential utilization of native prairie grasses from western Canada as ethanol feedstock. Canadian J. Plant Sci. 84,1067-1075.

Jefferson, P.G., McCaughey, W.P., May, K., Woosaree, J., MacFarlane, L., and Wright, S.M.B. (2002) Performance of American native grass cultivars in the Canadian Prairie Provinces. Native Plant J. 3,24-33. 
Jensen, K.B., Zhang, Y.F., and Dewey, D.R. (1990) Mode of pollination of perennial species of the Triticeae in relation to genomically defined genera. Can. J. plant Sci. 70,215-225.

Jin, H., Plaha, P., Park, J.Y., Hong, C.P., Lee, I.S., Yang, Z.H., Jiang, G.B., Kwak, S.S., Liu, S.K., Lee, J.S., Kim, Y.A., and Lim, Y.P. (2006) Comparative EST profiles of leaf and root of Leymus chinensis, a xerophilous grass adapted to high $\mathrm{pH}$ sodic soil. Plant Scie. 170,1081-1086.

Jung, H.G., and Engels, F.M. (2002) Alfalafa stem tissues: Cell-wall deposition, composition and degradability. Crop Sci. 42,524-534.

Jung, J.G., and Vogel, K.P. (1992) Lignification of switchgrass (Panicum virgatum) and big bluestem (Andropogon gerardii) plant parts during maturation and its effect on fiber degradability. J. Sci. Food Agric. 59,169-176.

Kindiger, B., and Dewald, C.L. (1997) The reproductive versatility of eastern gamagrass. Crop Sci. 37,1351-1360.

Kishii, M., Yamada, T., Sasakuma, T., and Tsujimoto, H. (2004) Production of wheat-Leymus racemosus chromosome addition lines. Theor. Appl. Genet. 109,255-260.

Kiss, G.B., Csanadi, G., Kalman, K., Kalo, P., and Okresz, L. (1993) Construction of a basic genetic map for alfalfa using RFLP, RAPD, isozyme and morphological markers. Mol. Gen. Genet. 238,129-137.

Lamb, J.F.S., and Jung, H.G. (2004) Environmental stability of stem quality traits in alfalfa. ASA,CSSA,SSSA Annual meetings, Seattle, WA, Oct 31-Nov 4, 2004 Abstr. 3885.

Lamb, J.F.S., Jung, H.G., Sheaffer, C.C., and Samac, D.A. (2007) Alfalfa leaf protein and stem cell wall polysaccharide yields under hay and biomass management systems. Crop Sci. 47,1407-1415.

Larson, S.R., and Mayland, H.F. (2007) Comparative mapping of fiber, protein, and mineral content QTLs in two interspecific Leymus wildrye full-sib families Mol. Breed. 20,331347.

Larson, S.R., Wu, X., Jones, T.A., Jensen, K.B., Chatterton, N.J., Waldron, B.L., Robins, J.G., Bushman, B.S., and Palazzo, A.J. (2006) Comparative mapping of growth habit, plant height, and flowering QTLs in two interspecific families of Leymus. Crop Scie. 46,25262539.

Lauriault, L.M., Kirsey, R.E., and VanLeeuwen, D.M. (2005) Performance of perennial coolseason forage grasses in diverse soil moisture environments, Southern High Plains, USA. Crop Sci. 45,909-915.

Lawrence, C.J., Seigfried, T.E., and Brendel, V. (2005) The maize genetics and genomics database. The community resource for access to diverse maize data. Plant Physiol. $138,55-58$.

Mandebvu, P., West, J.W., Froetschel, M.A., Hatfield, R.D., Gates, R.N., and Hill G.M. (1999a) Effect of enzyme or microbial treatment of bermudagrass forages before ensiling on cell wall composition, end products of silage fermentation and in situ digestion kinetics. Anim. Feed Sci. and Tech. 77,317-329.

Mandebvu, P., West, J.W., Hill, G.M., Gates, R.N., Hatfield, R.D., Mullinix, B.G., Parks, A.H., and Caudle, A.B. (1999b) Comparison of Tifton 85 and coastal bermudagrasses for yield, nutrient traits, intake, and digestion by growing beef steers. J. Anim. Sci. 77,15721586.

Marquez-Ortiz, J.J., Lamb, J.F.S., Johnson, L.D., Barnes, D.K., and Stucker, E.E. (1999) Heritibility of crown traits in alfalfa. Crop Sci. 39,38-43.

Marten, G.C. (1989) Breeding forage grasses to maximize animal performance. In D.A. Sleper et al. (eds.) Contributions from Breeding Forage and Turf Grasses. CSSA Special Publication No 15, CSSA, Madison, WI. pp. 71-104. 
Marten, G.C., Clapp, C.E., and Larson, W.E. (1979) Effects of municipal wastewater effluent and cutting management on persistence and yield of eight perennial forages. Agron. J. $71,650-658$.

Marten, G.C. and Hovin, A.W. (1980) Harvest schedule, persistence, yield, and quality interactions among four perennial grasses. Agron. J. 73,378-387.

Martínez-Reyna, J.M., and Vogel, K.P. (2002) Incompatibility systems in switchgrass. Crop Sci. 42,1800-1805.

Marum, P., Hovin, A.W., and Marten, G.C. (1979) Inheritance of three groups of indole alkaloids in reed canarygrass. Crop Sci. 19,539-544.

Marum, P., Hovin, A.W., Marten, G.C., and Shenk, J.S. (1979) Genetic variability for cell wall constituents and associated quality traits in reed canarygrass. Crop Sci. 19,355-360.

Maurer, D.A. and Zedler, J.B. (2002) Differential invasion of a wetland grass explained by tests of nutrients and light availability on establishment and clonal growth. Oecologia 131,279-288.

McGregor, S.E. (1976) Insect pollination of cultivated crop plants. USDA Agric. Handbook No. 496.

McWilliam, J.R., and Neal-Smith, C.A. (1962) Tetraploid and hexaploid chromosome races of Phalaris arundinacea L. Aust. J. Agric. Res. 13,1-9.

Mislevy, P., Brown, W.F., Caro-Costas, R., Vicente-Chandler, J., Dunavin, L.S., Hall, D.W., Kalmbacher, R.S., Overman, A.J., Ruelke, O.C., Sonada, R.M., Sotomayor-Rios, A., Stanley, Jr., R.L., and Williams, M.J. (1989a) 'Florico' stargrass. Circ. S-361. Fla. Agric. Exp. Stn., Gainesville.

Mislevy, P., Brown, W.F., Dunavin, L.S., Hall, D.W., Kalmbacher, R.S., Overman, A.J., Ruelke, O.C., Sonada, R.M., Stanley, Jr., R.L., and Williams, M.J. (1989b) 'Florona' stargrass. Circ. S-362. Fla. Agric. Exp. Stn., Gainesville.

Mitchell, R.B., Masters, R.A., Waller, S.S., Moore, K.J., and Moser, L.E. (1994) Big bluestem production and forage quality responses to burning date and fertilizer in tallgrass prairies. J. Prod. Agric. 7,355-359.

Mitchell, R.B., Vogel, K.P., Anderson, B.E., Klopfenstein, T.J., and Masters, R.A. (2003) Evaluation of four big bluestem populations under grazing. Agron. Abstr., 2-4 November 2003, Denver, CO.

Mitchell, R.B., Vogel, K.P., Klopfenstein, T.J., Anderson, B.E., and Masters, R.A. (2005) Grazing evaluation of big bluestems bred for improved forage yield and digestibility. Crop Sci. 45,2288-2292.

Monson, W.G., Lowry, R.S., and Forbes, Jr., I. (1969) In vitro nylon bag vs. two-stage in vitro digestion: Comparison of two techniques for estimating dry-matter digestibility of forages. Agron. J. 61,587-589.

Muir, J.P., Sanderson, M.A., Ocumpuaugh, W.R., Jones, R.M., and Reed, R.L. (2001) Biomass production of 'Alamo' switchgrass in response to nitrogen, phosphorus, and row spacing. Agron. J. 93,896-901.

Nelson, R.G., Langemeier, M.R., and Ohlenbusch, P.D. (1994) Herbaceous energy crop production feasibility using conservation reserve program acreage. In Proceedings of the Annual Conference of the American Solar Energy Society. San Jose, CA. pp. 326-331.

Newell, L.C. (1968) Effects of strain source and management practice on forage yields of two warm-season prairie grasses. Crop Sci. 8,205-210.

Norrmann, G.L., and Keeler, K.H. (2003) Cytotypes of Andropogon gerardii Vitman (Poaceae): Fertility and reproduction of aneuploids. Bot. J. Linnean Soc. 141,95-103.

Norrmann, G.L., Quarin, C.L., and Keeler, K.H. (1997) Evolutionary implications of meiotic chromosome behavior, reproductive biology, and hybridization in 6x and 9x cytotypes of Andropogon gerardii (Poaceae). Am. J. Bot. 84,201-207. 
Perry, L.J., and Baltensperger, D.D. (1979) Leaf and stem yields and forage quality of three N fertilized warm season grasses. Agron. J. 71,355-358.

Peters, L.V., and Newell, L.C. (1961) Hybridization between divergent types of big bluestem, Andropogon gerardii Vitman and sand bluestem, Andropogon hallii Hack. Crop Sci. $1,359-363$.

Prine, G.M., Mislevy, P., Stanley, R.L., Jr., Dunavin, L.S., and Bransby, D.I. (1991) Field production of energycane elephantgrass and sorghum in southeastern United States. In D.L. Klass (ed.) Proc. Final Program of Conference on Energy from Biomass and Wastes XV. Paper No. 24, 8pp.

Prine, G.M., Stricker, J.A., and McConnell, W.V. (1997) Opportunities for bioenergy development in lower south USA. Proc. 3rd Biomass Conference of the America: Making a Business from Biomass in Energy, Environment, Chemicals, Fibers and Materials. 1,227235.

Qi, L.L., Wang, S.L., Chen, P.D., Liu, D.J., Friebe, B., and Gill, B.S. (1997) Molecular cytogenetic analysis of Leymus racemosus chromosomes added to wheat. Theor. Appl. Genet. 95,1084-1091.

Redfearn, D.D., and Nelson, C.J. (2003) Grasses for southern areas. In R.F. Barnes, C.J. Nelson, M. Collins, K.J. Moore (eds.) Forages: Introduction to Grassland Agriculture, Blackwell, Ames, IA, pp. 149-169.

Reynolds, S.G., and Sini, O.V. (1976) A comparison of local and hybrid elephantgrass. Alfan. Agric. Bull. 1,1-4.

Riley, R.D., and Vogel, K.P. (1982) Chromosome numbers of released cultivars of switchgrass, indiangrass, big bluestem, and sand bluestem. Crop Sci. 22,1082-1083.

Rumbaugh, M.D., Caddel, J.L., and Rowe, D.E. (1988) Breeding and quantitative genetics. In A.A. Hanson et al. (eds.) Alfalfa and Alfalfa Improvement, ASA-CSSA-SSSA, Madison, WI. pp. $777-808$.

Russelle, M.P. (2001) Alfalfa. Amer. Sci. 89,252-261.

Sachs, A.P.W. and Coulman, B.E. (1983) Variability in reed canarygrass collections from Eastern Canada. Crop Sci. 23,1041-1044.

Sage, R.F., Li, M., and Monson, R.K. (1999) The taxonomic distribution of $\mathrm{C}_{4}$ photosynthesis. In R.F. Sage and R.K. Monson (eds.) $\mathrm{C}_{4}$ Plant Biology, Academic Press, New York. pp. 551-584.

Samac, D.A., Jung, H.G., and Lamb, J.F.S. (2006) Development of alfalfa (Medicago sativa L.) as a feedstock for production of ethanol and other bioproducts. In S. Minteer (ed.) Alcoholic Fuels, CRC Press, Boca Raton, FL. pp. 79-98.

Schank, S.C., and Diz, D.A. (1991) A seeded type of hybrid hexaploid elephantgrass with potential of livestock production in the tropics and subtropics. In Proc. Int. Conf. on Livestock in the Tropics. 5-8 May 1991. Institute of Food and Agricultural Sciences, University of Florida, Gainesville, FL. pp. A7-A13.

Schank, S.C., Diz, D.A., Bates, D.B., and Thompson, K.E. (1993) Genetic improvement of napiergrass and hybrids with pearl millet. Biomass Bioenerg. 5,35-40.

Schank, S.C., and Hanna, W.W. (1995) Usage of Pennisetum in Florida and the tropics. In Proc. Intl. Conf. on Livestock in the Tropics. 7-10 May 1995. Institute of Food and Agricultural Sciences, University of Florida, Gainesville, FL. pp. 1-13.

Schank, S.C., Smith, R.L., and Russo, S. (1989) Characterization of genetic variability among accessions and crosses of napiergrass, Pennisetum purpurem. Proc. XVI Int. Grassland Conf. pp. 341-342.

Sheaffer, C.C., and Marten, G.C. (1995) Reed canarygrass. In R.F. Barnes et al. (eds.) Forages Vol. I. An Introduction to Grassland Agriculture, Iowa State University Press, Ames, IA. pp. $335-343$ 
Sheaffer, C.C. Marten, G.C., Rabas, D.L., Martin, N.P., and Miller, D.W. (1990) Reed canarygrass. Minnesota Agric. Exp. Stn. Bull. 595.

Skerman, P.J., and Riveros, F. (1990) Tropical Grasses. Plant production and protection series 23. FAO, Rome, Italy.

Smith, R.L., Chowdhury, M.K.U., and Schank, S.C. (1989) Use of restriction-length polymorphism (RFLP) markers in genetics and breeding of napiergrass. Proc. Soil Crop Sci. Soc. Florida. 48,13-19.

Sollenberger, L.E., Prine, G.M., Ocumpaugh, W.R., Hanna, W.W., Jones, Jr. C.S., Schank, S.C., and Kalmbacher, R.S. (1988) 'Mott' dwarf elephantgrass-a high quality forage for the subtropics and tropics. Fla. Agric. Exp. Stn. Circ. S-356. Gainesville.

Sollenberger, L.E., Williams, M.J., and Jones, Jr., C.S. (1990) Vegetative establishment of dwarf elephantgrass: Effect of planting date, density, and location. Proc. Soil Crop Sci. Soc. of Fla. 50,47-51.

Springer, T.L., and Dewald, C.L. (2004) Eastern gamagrass and other Tripsacum species In L.E. Moser et al. (eds.) Warm-Season $\left(\mathrm{C}_{4}\right)$ Grasses. Agron. Monogr. 45. ASA-CSSASSSA, Madison, WI.

Springer, T.L., Dewald, C.L., Sims, P.L., Gillen, R.L., Louthan, V.H., Cooper, W.J., Taliaferro, C.M., Maura, Jr., C., Pfafe, S., Wynia, R.L., Henry, J., Brukerhoff, S.B., Van de Grinten, M., Salon, P.R., Houck, Jr., M., and Esquivel, R.G. (2006) Registration of 'Verl' eastern gamagrass. Crop Sci. 46,477-478.

Sreenath, H.K., Koegel, R.G., Moldes, A.B., Jeffries, T.W., and Straub, R.J. (1999) Enzymatic saccharification of alfalfa fibre after liquid hot water pretreatment. Process Biochem. $35,33-41$.

Sreenath, H.K., Koegel, R.G., Moldes, A.B., Jeffries, T.W., and Straub, R.J. (2001) Ethanol production from alfalfa fiber fractions by saccharification and fermentation. Process Biochem. 36,1199-1204.

Stubbendieck, J., Hatch, S.L., and Butterfield, C.H. (1991) North American Range Plants. University of Nebraska Press, Lincoln, NE.

Taliaferro, C.M., Anderson, J.A., Richardson, W.L., Baker, J.L., Coleman, S.W., Phillips, W.A., Sandage, L.J., Moyer, J.L., Hanson, T.L., Kallenbach, R.L., and Crawford, R.J. (2002) Registration of 'Midland 99' bermudagrass. Crop Sci. 42,2212-2213.

Taliaferro, C.M., and Richardson, W.L. (1980) Registration of 'Hardie' bermudagrass. Crop Sci. 20,413 .

Taliaferro, C.M., Roquette, Jr., F.M., and Mislevy, P. (2004) Bermudagrass and stargrass. In L.E. Moser et al. (eds.) Warm-Season $\left(\mathrm{C}_{4}\right)$ Grasses. Agron. Monogr. 45. ASA-CSSASSSA, Madison, WI. pp. 417-475.

Tergas, L.E., and Urrea, G.A. (1985) Effect of fertilization on the yield and nutritive value of tropical forages on an ultisol in Columbia. Trop.-Anim. Prod. (Mexico) 10,68-75.

Tiffany, D.G., Jordan, B., Deitrich E., and Vargo-Daggett, B. (2006) Energy and chemicals from native grasses: Production, transportation, and processing technologies considered in the northern Great Plains. Staff Paper P06-11. Dept. of Applied Economics. University of Minnesota, Minneapolis/St. Paul. Available at: www1.umn.edu/iree/pdfs. Accessed $12 / 4 / 2006$.

Tilley, J.M.A., and Terry, R.A. (1963) A two-stage technique for in vitro digestion of forage crops. J. Br. Grassl. Soc. 18,104-111.

USDA-ARS, National Genetic Resources Program (2007) Germplasm Resources Information Network - (GRIN) National Germplasm Resources Laboratory, Beltsville, Maryland. http://www.ars-grin.gov/cgi-bin/npgs/html/tax_search.pl

USDA-NASS, Agricultural Statistics (2004) http://www.usda.gov/nass/pubs/agr04/04_ch6.pdf USDA-NRCS, (1998) Plant-materials.nrcs.usda.gov/pmc/MDPMC/rel97_contents.html. USDA Natural Resources Conservation Service. National Plants Materials Center. 
USDA-NRCS, (2006) Eastern gamagrass (Tripsicum dactyloides): A plant for forage, conservation, and bioenergy. http://directives.sc.egov.usda.gov/media/pdf/tn_b_74_a.pdf

Vicente-Chandler, J., Abruna, F., Caso-Costas, R., Figarella, J., Silva, S., and Pearson, R. (1974) Intensive grassland management in the humid tropics of Puerto Rico. Univ. Puerto Rico Bull. 233.

Vicente-Chandler, J., Silva, S., and Figarella, J. (1959) The effect of nitrogen fertilization and frequency of cutting on the yield and composition of three tropical grasses. Agron. J. 51,202-206.

Vogel, K.E. (2000) Improving warm-season forage grasses using selection, breeding and biotechnology. In K.J. Moore and B.E. Anderson (eds.) Native Warm-Season Grasses: Research Trends and Issues. CSSA Special Pub. No. 30, Madison, WI. pp. 83-106.

Vogel, K.E., and Jung, H.G. ( 2001) Genetic modification of herbaceous plants for feed and fuel. Crit. Rev. Plant Sci. 20,15-49.

Vogel, K.E., and Mitchell, R.B. (2003) Breeding big bluestem for improved performance by grazing livestock. Agron. Abstr. ASA-CSSA-SSSA, 2-6 November 2003, Denver, CO.

Vogel, K.E., Mitchell, R.B, Klopfenstein, T.J., and Anderson, B.E. (2006a) Registration of 'Bonanza' big bluestem. Crop Sci. 46,2313-2314.

Vogel, K.E., Mitchell, R.B., Klopfenstein, T.J., and Anderson, B.E. (2006b) Registration of 'Goldmine' big bluestem. Crop Sci. 46,2314-2315.

Volenec, J.J., Cherney, J.H., and Johnson, K.D. (1987) Yield components, plant morphology, and forage quality of alfalfa as influenced by plant population. Crop Sci. 27,321-326.

Waller, S.S., and Lewis, J.K. (1979) Occurrence of $\mathrm{C}_{3}$ and $\mathrm{C}_{4}$ photosynthetic pathways in North American grasses. J. Range Manage. 32,12-28.

Wasser, C.H. (1982) Ecology and culture of selected species useful in revegetating disturbed lands in the West. USDA FWS/OBS-8256. Washington, DC.

Weaver, J.E. (1968) Prairie Plants and Their Environment. University of Nebraska Press, Lincoln, NE.

Weimer, P.J., Dien, B.S., Springer, T.L., and Vogel, K.P. (2005) In vitro gas production as a surrogate measure of the fermentability of cellulosic biomass to ethanol. Appl. Microbiol. Biotechnol. 67,52-58.

Weimer, P.J., and Springer, T.L. (2007) Fermentability of eastern gamagrass, big bluestem, and sand bluestem grown across a wide variety of environments. Bioresource Technol. 98,1615-1621.

Woodard, K.R. and Prine, G.M. (1990) Propagation quality of elephant grass stems as affect by the fertilization rate used on nursery plants. Soil Crop Sci. Soc Fla. Proc. 49,173-176.

Woodard, K.R., and Prine, G.M. (1991) Forage yield and nutritive value of elephantgrass as affected by harvest frequency and genotype. Agron. J. 83,541-546.

Woodard, K.R., Prine, G.M., and Ocumpaugh, W.R. (1985) Techniques in the establishment of elephantgrass (Pennisetum purpureum Schum.). Soil Crop Sci. Soc. Fla. Proc. 44,216221.

Wright, N.A. (1990) Screening of herbaceous species for energy crops on wet soils in Ohio. In J. Janick and J.E. Simon (eds.) Advances in New Crops. Proc. 1st Natl. Symp. New Crops. 23-26 October 1988, Indianapolis, IN. Timber Press, Portland, OR. pp. 263-267.

Wu, X.L., Larson, S.R., Hu, Z.M., Palazzo, A.J., Jones, T.A., Wang, R.R., Jensen, K.B., and Chatterton, N.J. (2003) Molecular genetic linkage maps for allotetraploid Leymus (Triticeae). Genome 46,627-646.

Xavier, D.F., de A. Botrel, M., Daher, R.F., Teixeira-Gomes, F., and Pereira, A.V. (1995) Caracterizaçâo morfológica e agronómicas de algumas cultivares de Capim-elefante. Documento N1 60, Empresa Brasileira de Pesquisa Agropecuaria (EMBRAPA), Brasil. 